\title{
Immunity and Inflammation in Epilepsy
}

\author{
Annamaria Vezzani ${ }^{1}$, Bethan Lang ${ }^{2}$, and Eleonora Aronica ${ }^{3,4,5}$ \\ ${ }^{1}$ Department of Neuroscience, IRCSS-Istituto di Ricerche Farmacologiche "Mario Negri," 20156 Milano, Italy \\ ${ }^{2}$ Nuffield Department of Clinical Neurosciences, John Radcliffe Hospital, Oxford OX3 9DU, United Kingdom \\ ${ }^{3}$ Department of (Neuro)Pathology, Academic Medical Center, University of Amsterdam, 1105 AZ Amsterdam, \\ The Netherlands \\ ${ }^{4}$ Department of (Neuro)Pathology, Swammerdam Institute for Life Sciences, Center for Neuroscience, \\ University of Amsterdam, 1105 AZ Amsterdam, The Netherlands \\ ${ }^{5}$ SEIN-Stichting Epilepsie Instellingen Nederland, Heemstede 2103 SW, The Netherlands \\ Correspondence: annamaria.vezzani@marionegri.it
}

This review reports the available evidence on the activation of the innate and adaptive branches of the immune system and the related inflammatory processes in epileptic disorders and the putative pathogenic role of inflammatory processes developing in the brain, as indicated by evidence from experimental and clinical research. Indeed, there is increasing knowledge supporting a role of specific inflammatory mediators and immune cells in the generation and recurrence of epileptic seizures, as well as in the associated neuropathology and comorbidities. Major challenges in this field remain: a better understanding of the key inflammatory pathogenic pathways activated in chronic epilepsy and during epileptogenesis, and how to counteract them efficiently without altering the homeostatic tissue repair function of inflammation. The relevance of this information for developing novel therapies will be highlighted.

\begin{abstract}
A major clinical need for epilepsy is to develop new drugs for controlling seizures in people with pharmacoresistant epilepsy. Moreover, the available treatments are symptomatic; therefore, disease-modifying therapies for preventing the onset or progression of the disease are missing. The key molecular mechanisms underlying the disease onset and its progression are still elusive, although some signaling pathways have recently been suggested to play a pathologic role (Pitkanen and Lukasiuk 2011). Experimental studies and clinical evidence obtained in animal models of epilepsy and human brain specimens from
\end{abstract}

various drug-resistant forms of epilepsy show the activation of the innate and adaptive immunity mechanisms and the induction of the associated inflammatory processes in the epileptogenic foci (Aronica and Crino 2011; Vezzani et al. 2011b). A role of inflammatory molecules in the generation of seizures had been first envisaged when selected anti-inflammatory treatments, in particular, steroids, immunoglobulins, and adrenocorticotropic hormone (ACTH), were shown to control seizures in pediatric epilepsies refractory to conventional anticonvulsive drugs (e.g., infantile spasms,

Editors: Gregory L. Holmes and Jeffrey L. Noebels

Additional Perspectives on Epilepsy: The Biology of a Spectrum Disorder available at www.perspectivesinmedicine.org

Copyright (C) 2016 Cold Spring Harbor Laboratory Press; all rights reserved; doi: 10.1101/cshperspect.a022699

Cite this article as Cold Spring Harb Perspect Med 2016;6:a022699 
A. Vezzani et al.

continuous spike and waves in sleep, and epilepsy in Rasmussen encephalitis [RE]). In addition, specific epileptic disorders have been associated with the presence of neuronal antigen-directed antibodies in plasma or cerebrospinal fluid (CSF). In some of these forms, the pathogenic role of some autoantibodies is suspected based on clinical and experimental findings (Bien et al. 2012). In recent years, immune cells producing inflammatory molecules were detected in surgically resected brain tissue from patients with pharmacoresistant epilepsies without an autoimmune etiology. A significant component of this inflammatory response was confined to brain resident cells (i.e., microglia, astrocytes, and neurons) and is defined as "neuroinflammation" (Vezzani et al. 2011b; Aronica et al. 2012b). Cytokines and related signaling molecules were among the most prominently overexpressed inflammatory mediators identified in epileptogenic brain tissue. Besides glial cells, inflammatory molecules are also produced and released by neurons and endothelial cells of the blood-brain barrier (BBB). Leukocytes can also contribute to the inflammatory responses in epilepsy (Iyer et al. 2010a; Vezzani et al. 2011b; Bien et al. 2012). A notable finding is that the inflammatory mediators (i.e., cytokines, chemokines, prostaglandins, complement system) detected in epilepsy brain specimens are not only effector molecules of the immune system promoting local inflammation and tissue recruitment of peripheral immune cells, but they function as "neuromodulators" (Vezzani et al. 2011c). In fact, they activate their cognate receptors expressed by neurons, thus directly affecting neuronal function and excitability (Viviani et al. 2007; Vezzani et al. 2011c). Specific inflammatory mediators were reported to significantly contribute to the mechanisms of seizure generation and to pharmacoresistence in experimental models (van Vliet et al. 2010; Vezzani et al. 2011b).

This article will describe the recent evidence related to the pathologic consequences of innate and adaptive immunity activation in human epilepsy, the mechanisms activated by inflammatory molecules or autoantibodies in target cells, and their relevance for the onset and progression of the disease. Finally, we will discuss the implications of these findings for epilepsy therapy.

\section{ACTIVATION OF INNATE IMMUNITY IN EXPERIMENTAL MODELS OF EPILEPSY}

Increasing evidence in animal models of epilepsy has shown a prominent role of glial cells in the biosynthesis and release of the inflammatory molecules (Aronica and Crino 2011; Vezzani et al. 2011b; Devinsky et al. 2013). These cells play the role of intrinsic innate immunity cells of the brain in concert with extravasated macrophages and granulocytes. In particular, epileptogenic brain injuries (i.e., brain insults leading to or increasing the risk of the development of epilepsy) or convulsive events (i.e., provoking acute seizures) rapidly activate microglia and astrocytes in the brain regions affected by the pathologic event (Fig. 1). Glia activation occurs also in genetic models of epilepsy, such as in rats with spike-and-wave discharges mimicking absence seizures (Akin et al. 2011), models of tuberous sclerosis (Wong and Crino 2012), and progressive myoclonus epilepsy of Unverricht-Lundborg type 1 (Tegelberg et al. 2012; Joensuu et al. 2014). Notably, glia activation occurs during epileptogenesis (i.e., the phase that precedes the onset of the disease and accompanies its progression) (Pitkanen and Engel 2014) both in symptomatic and genetic epilepsy models, and is maintained in the chronic epilepsy phase (when the disease is established). Both microglia and astrocyte activation correlates with the number of spontaneous seizures in animal models (Ravizza et al. 2008; Filibian et al. 2012); in particular, the extent of astrocytes activation as assessed by their content of myoinositol and $S 100 \beta$ predicts the extent of cell loss and the frequency of spontaneous seizures in epileptic rats, respectively (Filibian et al. 2012). Increased numbers of macrophages and neurotrophils in the brain have also been reported during epileptogenesis (Fabene et al. 2008; Zattoni et al. 2011).

On their activation, glial cells release a number of proinflammatory cytokines, for example, interleukin (IL)-1 $\beta$, high-mobility group box 1 (HMGB1), tumor necrosis factor (TNF)- $\alpha$, 


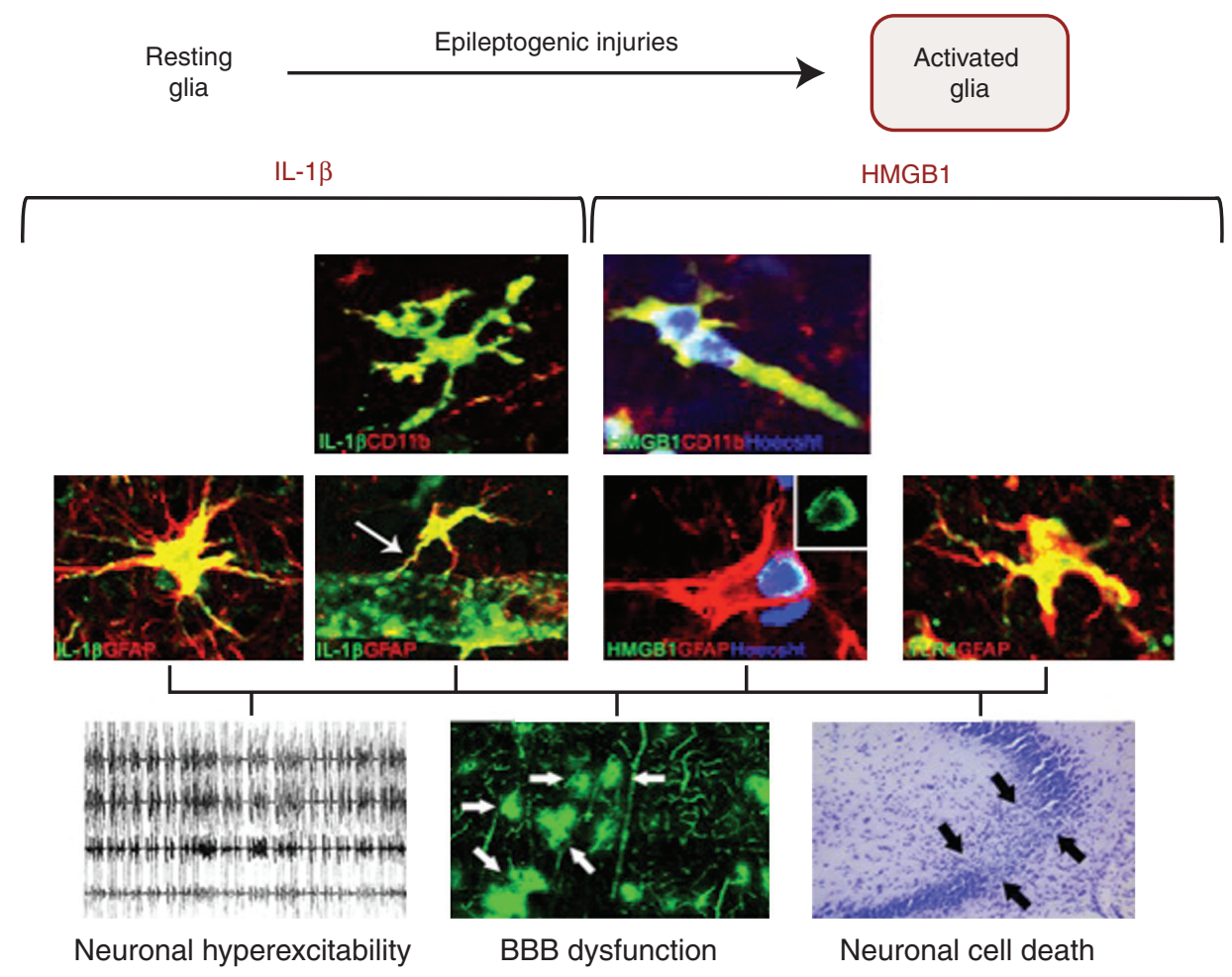

Figure 1. Pathophysiological consequences of glia activation in epilepsy. Epileptogenic injuries and recurrent seizures activate glial cells (microglia and astrocytes), which release inflammatory molecules with proictogenic properties, such as interleukin (IL)-1 $\beta$ and high-mobility group box 1 (HMGB1), therefore triggering neuroinflammation. This event leads to changes in brain physiology because cytokines provoke neuronal hyperexcitability, blood-brain barrier (BBB) dysfunction, and contribute to neuronal cell loss. These pathologic sequelae ( panels in bottom row), in turn, perpetuate neuroinflammation, thereby leading to chronic lowering of seizure threshold, and thus promoting epileptogenesis and seizure generation. Panels (top and middle rows) depict confocal microscope pictures from the forebrain tissue of epileptic rats, showing IL-1 $\beta$ and HMGB1 expressed both in activated glial fibrillary acidic protein (GFAP)-positive astrocytes and CD11b-positive microglia. No IL-1 $\beta$ staining in glia is detectable in physiological conditions (not shown). IL-1 $\beta$-positive astrocytes are observed in epilepsy tissue, also in close apposition to brain vessels (white arrow). HMGB1 is bound to nuclei in brain physiology (not shown), while it translocates to cytoplasm in epilepsy tissue as depicted in the related panels by cytoplasmatic and perinuclear staining in activated CD11b-positive microglia and GFAP-positive astrocytes, respectively. Toll-like receptor 4 (TLR4) mediates the proconvulsive effects of HMGB1; their activation in astrocytes (second row, bottom panel) promotes neuroinflammation, whereas their activation in neurons (not shown) mediates hyperexcitability (see Maroso et al. 2010).

and related molecules, thus initiating a sustained cascade of molecular events in the brain and its microvasculature, which increases neuronal excitability and lowers seizure threshold as shown in the experimental setting (Vezzani et al. 2011c, 2013b; Aronica et al. 2012b). Brain inflammation may also promote cell loss; in particular, status-epilepticus-induced up-regulation of neuronal cyclooxygenase 2 (COX-2) during epileptogenesis has been shown to play a key role in the occurrence of neuronal cell death. This effect was mediated by prostaglandin E2 (PGE2)-induced activation of the E-prostanoid 2 (EP2) receptors (Rojas et al. 2014). A role in cell loss has also been ascribed to the activation of the complement cascade in neurons and glia (also eliciting seizures) (Xiong et al. 2003) and to neurotrophils that may enter the brain 
A. Vezzani et al.

following brain injury (Fabene et al. 2008; Zattoni et al. 2011).

The Role of Innate Immunity in Seizures and Epileptogenesis: Focus on IL-1R/Toll-Like Receptor (TLR) Pathway

The IL-1 receptor $(\mathrm{R}) /$ TLR pathway is the prototypical innate immunity signal activated during the tissue response to infections. It is instrumental for recognition of pathogens (i.e., pathogen-associated molecular patterns [PAMPs]) and their removal, thereafter promoting tissue healing by activating the "homeostatic-type" of tissue inflammation (Ulevitch and Tobias 1995). In epilepsy, in the absence of pathogens, this signaling is aberrantly activated in glia and neurons by endogenous molecules (i.e., damage-associated molecular patterns [DAMPs] ) released by injured or activated brain cells, giving rise to the so-called "sterile inflammation" (Bianchi 2007). Although the response to pathogens engages both the innate and adaptive arms of the immune system, sterile inflammation is predominantly driven and sustained by the activation of innate immunity cells, pivotally represented in the brain by microglia and astrocytes. These cells recognize DAMPs, including HMGB1, S100 proteins, adenosine triphosphate (ATP), migration inhibitory factor-related protein 8 (MRP8), products of extracellular matrix degradation, and, together with IL-1 $\beta$, they activate inflammatory pathways, in part overlapping with those activated by infection (Tsan and Gao 2004; Bianchi 2007). These molecules target their receptors expressed by glia, neurons, and the microvasculature. Signaling activation in glia is pivotal for generating tissue inflammation via NF- $\kappa \mathrm{B}$-dependent transcriptional up-regulation of various inflammatory genes. Signaling activation in endothelial cells of the $\mathrm{BBB}$ induces up-regulation of adhesion molecules for the recruitment of circulating leukocytes and provokes breakdown of tight junctions contributing to $\mathrm{BBB}$ damage. Activation of this pathway in neurons reduces seizure threshold, thus playing a crucial role in seizure generation and recurrence in epilepsy models (Vezzani et al. 2011c, 2013a,b).
Pharmacological studies in neonatal/preadolescent and adult rodents with acute or chronic seizures, or exposed to a brain or systemic inflammatory challenge using lipopolysaccharide (LPS), showed that proinflammatory cytokines, such as IL- $1 \beta$, TNF- $\alpha$, and HMGB1, promote seizure generation and recurrence, and contribute to behavioral deficits mimicking cognitive dysfunctions and depression, which often represent epilepsy comorbidities (Riazi et al. 2010; Galic et al. 2012; Pineda et al. 2013; Vezzani et al. 2013a). Pharmacologic antagonism of specific proinflammatory pathways activated in glia and neurons has been attempted in animals with acute or chronic seizures: the data showed a reduction of $50 \%-$ $70 \%$ of seizure recurrence by targeting IL$1 \mathrm{R} 1 / \mathrm{TLR} 4$ signaling or $\mathrm{TNF}-\alpha / \mathrm{p} 55$ receptors demonstrating a significant anti-ictogenic effect of such treatments (Vezzani et al. 2011c; Balosso et al. 2013; Iori et al. 2013; Weinberg et al. 2013). Pharmacological blockade of individual proinflammatory pathways after an epileptogenic injury and before epilepsy develops induced disease-modifying effects (e.g., neuroprotection, decreased frequency and severity of chronic seizures, reduced comorbidities) in animal models, although not preventing the onset of the disease (Vezzani et al. 2013a,b; Rojas et al. 2014). Accordingly, recent findings show that TLR4 knockout mice or rats treated with a cocktail of anti-IL-1 $\beta$ drugs and COX-2 inhibitor develop less severe cell loss and milder epilepsy after status epilepticus (Iori et al. 2013; Kwon et al. 2013; Noé et al. 2013). This evidence suggests that complementary anti-inflammatory strategies may be required for attaining an effective control of brain inflammation because the inflammatory process is highly reverberant and broad, and various pathways are activated in concert, particularly during epileptogenesis. In this context, it will be important to identify key "master regulators" of pathologic brain inflammation in epilepsy for promoting its fast and efficient resolution, thus preventing the deleterious consequences of uncontrolled and persistent brain inflammation. One innovative strategy for attaining upstream efficient control of brain inflammation is indicated by the identifi- 
cation of a family of microRNAs (miRNAs), small noncoding RNAs, acting as key modulators of the innate immune response and the associated inflammation (Gantier 2010; Quinn and O'Neill 2011; Jimenez-Mateos and Henshall 2013). Using genome-wide miRNA array platforms, subsets of differentially expressed miRNAs have been measured in rodent brain and blood after ischemic stroke, intracerebral hemorrhage, and seizures, with unique signatures and specific functions in seizure models (Liu 2010; Jimenez-Mateos 2012; Gorter et al. 2014). Notably, $\sim 20 \%$ of brain-expressed miRNAs are altered in epilepsy (Jimenez-Mateos and Henshall 2013). Changes in specific miRNA expression occur in glia and neurons in human temporal lobe epilepsy (TLE) foci, and bioinformatic analysis identified the immune/inflammatory responses as their most prominent targets (Kan et al. 2012a). Accordingly, the immune/inflammatory responses are the biological processes more significantly altered during epileptogenesis (Gorter et al. 2006). In particular, miR146a is specifically associated with the modulation of IL-1R1/TLR4 signaling (Quinn and O'Neill 2011) and is prominently up-regulated in glial cells in human TLE, although increased expression has been detected also in neurons (Aronica et al. 2010). miR146a expression is induced in human astrocytes cell cultures by IL-1 $\beta$ and HMGB1 (Iyer et al. 2012). The increased expression of miR146a induced by IL- $1 \beta$ is associated with a parallel decrease of IRAK-1-mediated signaling, thus indicating that the miR146a inhibits IL-1R1/TLR4 intracellular signal transduction. Transfection with locked nucleic acid (LNA)-anti-miR146a before IL- $1 \beta$ stimulation prevented this signaling down-regulation and, accordingly, enhanced IL$1 \beta$-mediated induction of cytokines and COX2. Finally, human astrocytes transfection with a specific miR146a synthetic mimic reduces IL$1 \beta$-induced signaling cascade and the related effector molecules (Iyer et al. 2012). These data suggest that miR146a is induced by cytokines in human glial cells as a negative-feedback mechanism to control the neuroinflammatory response. In epilepsy, however, this control mechanism may be inefficient as previously shown for other defective endogenous anti-inflammatory mechanisms, such as the insufficient induction of IL-1R antagonist (IL-1Ra) (De Simoni et al. 2000; Oprica et al. 2003; Ravizza et al. 2006), which is pivotal for controlling IL- $1 \beta$ signaling, the CD59 inhibitor of the complement cascade, or the ATF-3 transcriptional factor-inhibiting TLR4 gene expression (Aronica et al. 2007; Pernhorst et al. 2013). Implementation of miR146a effects may represent, therefore, a novel strategy for upstream control of the pathologic brain inflammatory response in epilepsy. Our recent evidence indeed shows that synthetic miR146a mimics significantly reduced seizures in mice (unpubl.).

\section{Mechanisms of Hyperexcitability Induced by Inflammatory Mediators}

Proinflammatory molecules, such as cytokines, chemokines, and prostaglandins, have an increasingly recognized "neuromodulatory" role mediated either by the direct activation of their cognate receptors in neurons or, indirectly, by autocrine receptor stimulation in glia leading to alterations of glial cell physiology, which, in turn, perturb glioneuronal communications (Aronica et al. 2012b; Devinsky et al. 2013). IL- $1 \beta$, TNF- $\alpha$, and IL- 6 and prostaglandins, such as PGE2 and PGF2a, modify voltage- and receptor-gated ion channel function via rapid activation of posttranslational mechanisms in neurons involving protein kinases (Viviani et al. 2007; Kulkarni and Dhir 2009; Vezzani et al. 2013b). Cytokines also promote changes in neuronal glutamate ( $N$-methyl-D-aspartate [NMDA] and AMPA) and $\gamma$-aminobutyric acid $(\mathrm{GABA})_{\mathrm{A}}$ receptor expression, and alter their molecular subunit composition by activating protein kinases (Stellwagen et al. 2005; Balosso et al. 2009). Cytokines may increase neuronal excitability also by inducing transcriptional down-regulation of glutamate transporter GLT-1 in astrocytes, and by promoting astrocytic release of ATP, glutamate, glycine, and D-serine, which, in turn, activate their neuronal receptors and enhance glutamatergic transmission (Devinsky et al. 2013). Cytokines are also released by perivascular astrocytes and microglia, there- 
A. Vezzani et al.

by contributing to BBB dysfunction in epilepsy (Vezzani and Friedman 2011). This phenomenon leads to brain extravasation of serum albumin, which promotes seizures by inducing cytokines in glia, and reducing Kir4.1 channels and gap-junction coupling in astrocytes (Friedman et al. 2009; Braganza et al. 2012; Frigerio et al. 2012).

Importantly, the same inflammatory molecules, their cognate receptors, and cell signaling contributing to experimental seizure generation were found to be induced in human brain specimens surgically resected from individuals affected by various drug-resistant forms of epilepsy (Vezzani et al. 2011b). This set of evidence reported in the next section highlights that the presence of these inflammatory molecules in the brain may represent a common pathologic substrate contributing to seizure mechanisms in different forms of symptomatic and genetically determined epilepsies.

\section{LEUKOCYTES IN SEIZURES}

There is evidence for the presence of the peripheral immune cells in models of epilepsy, and such a contribution differs depending on the nature of the epileptogenic stimuli. In particular, lymphocytes have been found in the hippocampus after status epilepticus induced by systemic injection of pilocarpine (Fabene et al. 2008) or intrahippocampal administration of kainic acid in mice (Zattoni et al. 2011). Active brain extravasation of these cells may contribute to alter BBB permeability properties (Fabene et al. 2008). The crucial question remains whether this phenomenon is relevant for tissue hyperexcitability or neuropathology. In pilocarpine-treated mice, leukocytes (i.e., neurotrophils, macrophages, and T cells) appear to play a detrimental role in epileptogenesis because mice lacking key adhesion molecules or those treated with anti-integrin antibodies develop a milder form of epilepsy and less neuropathology (Fabene et al. 2008). Differently, in intracerebral kainic acid-treated mice, macrophages and $\mathrm{T}$ cells play a protective role by preventing neurotrophil extravasation and delaying the onset and reducing the recurrence of spontaneous seizures (Zattoni et al. 2011). As in human TLE epilepsy tissue, the extent of T-cell infiltrates in the rodent brain is limited and mostly restricted to the perivascular space (Ravizza et al. 2006, 2008; Fabene et al. 2008; Marchi et al. 2010; Bien et al. 2012).

\section{INFLAMMATION IN PATIENTS WITH REFRACTORY FOCAL EPILEPSY}

Over the past decade, an increasing number of clinical and neuropathological observations show that activation of inflammatory processes occurs in a variety of focal epilepsies without infectious or immune-mediated etiology, such as hippocampal sclerosis (HS) and focal malformations of cortical development (MCD), focal cortical dysplasia (FCD), and cortical tubers in tuberous sclerosis complex (TSC) (Fig. 2) (for reviews, see Aronica and Crino 2011, 2014; Vezzani et al. 2011a, 2013a; Aronica et al. 2012b).

\section{HS}

HS is the most common neuropathological finding in patients undergoing surgery for intractable TLE (Blumcke et al. 2013). Neuropathological examination of surgical specimens from TLE patients with HS provides evidence of a sustained activation of the innate immune response, which involves both astrocytes and cells of the microglia/macrophages lineage (Sheng et al. 1994; Beach et al. 1995; Aronica and Gorter 2007; Ravizza et al. 2008).

Positron emission tomography (PET) has been used in an attempt to image activation of astrocytes and microglial/macrophages in vivo using radioligands for the detection of the translocator protein (TSPO) $(18 \mathrm{kDa}$, a marker of neuroinflammation) (Chen and Guilarte 2008; Cosenza-Nashat et al. 2009). A recent study reported an increased uptake of radioactivity after injection of 11C-PBR28 (a new tracer for the detection of TSPO) ipsilateral to the seizure focus (within the hippocampus) of TLE patients, particularly in patients with HS (Hirvonen et al. 2012). Additional studies are, however, needed to determine the clinical utility of imaging TSPO, and to correlate increases in 


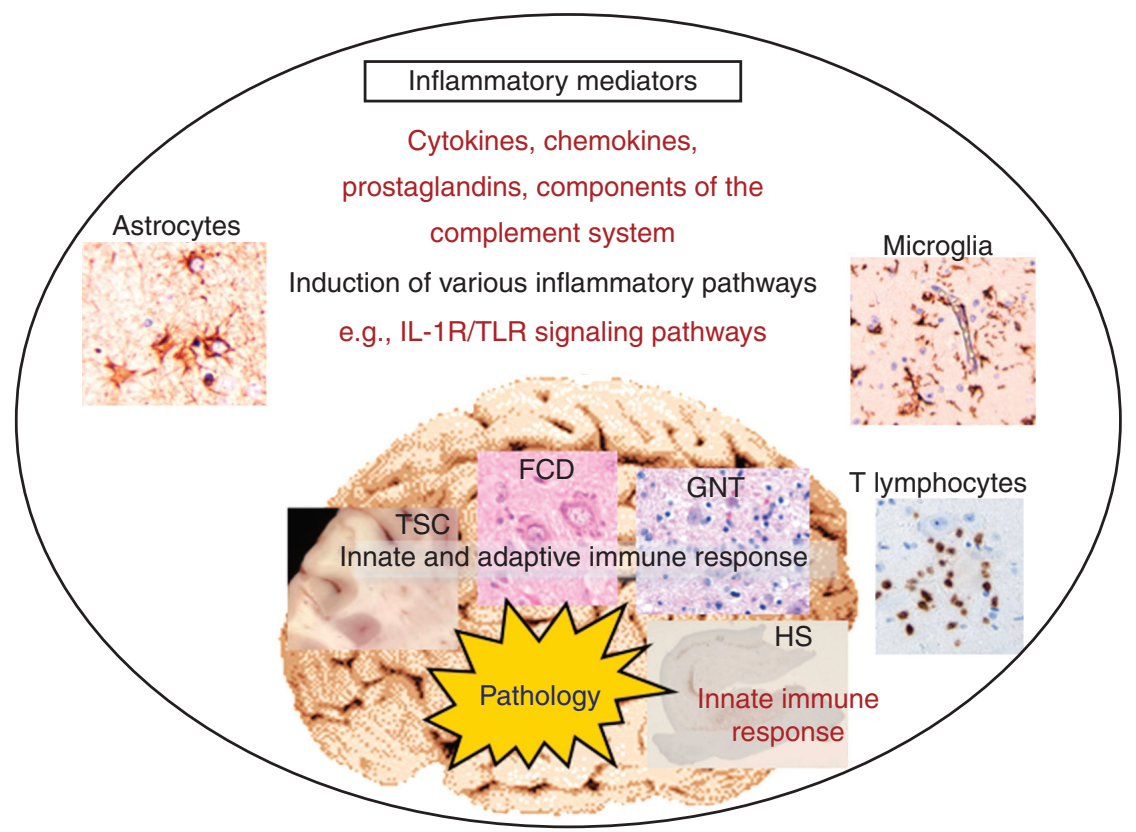

Figure 2. Inflammation in the brain of patients with refractory focal epilepsy. Schematic drawing summarizing neuropathological observations that indicate the activation of inflammatory processes, and the concomitant synthesis and release of inflammatory molecules (with neuromodulatory properties) in a variety of focal epilepsies, such as hippocampal sclerosis (HS), focal malformations of cortical development (MCD) (focal cortical dysplasia [FCD] type II, and cortical tubers in tuberous sclerosis complex [TSC]) and glioneuronal tumors (GNTs). Neuropathological examination of surgical specimens from patients with HS provides evidence of a sustained activation of the innate immune response, which involves both astrocytes and microglial cells. Neuropathological examination of surgical specimens from patients with FCD, TSC, and GNT provides evidence of activation of both innate and the adaptive immune response (with the presence of $\mathrm{T}$ lymphocytes within the lesion). The identification of proinflammatory pathways, such as the interleukin (IL)-1R/toll-like receptor (TLR)-signaling pathway, involved in ictogenesis in experimental models may create the basis to develop effective therapeutic strategies to control pharmacoresistant seizures.

TSPO binding with the neuropathological finding in patients undergoing epilepsy surgery.

Large-scale gene-expression data, as well as immunohistochemical studies, support the association of astrogliosis and microglial cell activation with the induction of major proinflammatory pathways in patients with TLE (Crespel et al. 2002; Aronica and Gorter 2007; Ravizza et al. 2008; van Gassen et al. 2008). In particular, the IL-1R/TLR-signaling pathways, which are activated in experimental models of seizures (see above), have been shown to be up-regulated (Vezzani et al. 2011a; Aronica et al. 2012b). Prominent overexpression of IL- $1 \beta$ and its receptor, IL-1R1, as well as TLR4 and its ligand, HMGB1, has been detected in HS specimens with a cellular and subcellular localization, which confirms the findings reported in chronic epileptic animals (Ravizza et al. 2008; Maroso et al. 2010). Moreover, a recent study shows a substantial correlation between TLR4 gene expression and seizure frequency in the hippocampus of patients with TLE (Pernhorst et al. 2013).

The complement system is another important mediator of the innate response. Components of the complement cascade may potentially contribute to a sustained inflammatory response and a destabilization of neuronal networks increasing vascular permeability, recruiting immune cells, activating glial cells, and enhancing production of chemokines and proinflammatory cytokines, such as IL- $1 \beta$ (for re- 
A. Vezzani et al.

view, see Lucas et al. 2006). Activation of the classical complement pathway observed in experimental models of epilepsy has been reported in human HS specimens with consistent astroglial and microglial expression of different complement components, such as $\mathrm{C} 1 \mathrm{q}, \mathrm{C} 3 \mathrm{c}$, and $\mathrm{C} 3 \mathrm{~d}$, particularly, within regions in which neuronal cell loss occurs (Aronica et al. 2007). Activation of the plasminogen system, involving neurons, reactive glial cells, and vascular endothelium, may act in concert contributing to the disturbance of the BBB and inflammation (Lo et al. 2002; Del Rosso et al. 2008). Accordingly, induction of both tissue plasminogen activator (tPA) and urokinase plasminogen activator (uPA) observed in different experimental models of epilepsy has been confirmed in HS specimens (Iyer et al. 2010b).

Several studies point to the critical role of chemokines in the control of acute and chronic neuroinflammation in epilepsy (for review, see Fabene et al. 2010). Both experimental and human TLE studies provide evidence of an up-regulation of components of the chemokine signaling pathways (de Lanerolle and Lee 2005; Aronica and Gorter 2007; van Gassen et al. 2008; Kan et al. 2012b; Xu et al. 2012). Interestingly, the chemokine fractalkine/CX3CL1 has been shown to modulate GABA-evoked currents in human epileptic brain tissue and the expression of its receptor CX3CR1 was increased in microglial cells, supporting the relation between neuroinflammation and GABAergic function in human TLE (Roseti et al. 2013).

The immunoproteasome is an emerging key player in antigen presentation, but also in cytokine regulation (Ferrington and Gregerson 2012; Bellavista et al. 2013), which has been recently shown to be deregulated in tissue from TLE patients (Mishto et al. 2011). Additional studies are, however, needed to better define the cellular distribution and the significance of this macromolecular complex in relation to the clinical course of epilepsy.

Recently, attention has been focused on the role of miRNAs as a new class of regulators of the innate and adaptive immune response (Sonkoly et al. 2008; Gantier 2010; Quinn and O’Neill 2011). Differential expression of several
miRNAs implicated in the regulation of the IL$1 \mathrm{R} / \mathrm{TLR}$-signaling pathways, such as miR146a, has been shown in both animal models and human TLE (Aronica et al. 2010; Iyer et al. 2012; Omran et al. 2012; Gorter et al. 2014). These observations suggest the potential for targeting miRNA as strategy for modulating inflammatory pathways in TLE, as well as in different epilepsyassociated glioneuronal lesions (Iyer et al. 2012).

\section{Focal Malformations of Cortical Development}

These forms, which include FCD and cortical tubers of patients with TSC, as well as glioneuronal tumors (GNTs), are among the most common causes of pharmacologically intractable epilepsy (Blumcke et al. 2009; Sisodiya et al. 2009; Aronica et al. 2012a; Barkovich et al. 2012; Thom et al. 2012; Aronica and Crino 2014).

Neuropathological examination of surgical specimens from patients with FCD provides evidence of activation of both the innate and adaptive immune responses and concomitant induction of various inflammatory pathways (Boer et al. 2006; Ravizza et al. 2006; Choi et al. 2009; Iyer et al. 2010a). Moreover, in a cohort FCD II case, the density of activated microglial cells significantly correlates with the duration of epilepsy, as well as with the frequency of seizures before surgical resection (Boer et al. 2006). Moreover, the number of activated microglial cells and CD3/CD8 positive T cells, as well as the expression of the major histocompatibility complex class I (MHC-I) in neuronal cells and the expression of complement components, IL$1 \beta$ and chemokines, was significantly higher in FCD type II than in FCD type I cortical specimens (Ravizza et al. 2006; Iyer et al. 2010a; Prabowo et al. 2013a), supporting the notion that these two types of FCD are pathologically distinct (Aronica and Crino 2014). In FCD II, there is also evidence of activation of the plasminogen system (Iyer et al. 2010b), overexpression of HMGB1 and its receptors (TLR2, TLR4, and RAGE) (Zurolo et al. 2011), and focal BBB disruption (Prabowo et al. 2013a). These observations together support the critical role of a sustained inflammatory response in FCD type 
Immunity and Inflammation in Epilepsy

II, thus revealing pathways common to different epileptogenic lesions (see above) (Aronica and Crino 2011, 2014; Vezzani et al. 2011a, 2013a).

Similarly to FCD II, a complex activation of proinflammatory signaling pathways has been reported in cortical tubers in TSC patients (Boer et al. 2008, 2010; Iyer et al. 2010b; Zurolo et al. 2011; Aronica and Crino 2014). Interestingly, evaluation of fetal TSC cases showed a prenatal activation of the innate immune response with premature activation of key inflammatory pathways, such as TLR signaling (Prabowo et al. 2012).

Finally, both gene expression and immunocytochemical studies provide evidence for a prominent activation of both innate and adaptive immune systems in GNT with prominent up-regulation of components in the IL-1R/ TLR pathways and the complement cascade (Aronica et al. 2005, 2008; Ravizza et al. 2006; Prabowo et al. 2013a). In ganglioglioma (GG), the inflammatory changes are associated with evidence of alterations in BBB permeability, albumin extravasation, and its uptake in tumor astrocytes (Prabowo et al. 2013a,b; Schmitz et al. 2013). Moreover, in GG, the expression of pS6 (marker of mammalian target of rapamycin [mTOR] pathway activation) positively correlates with the presence of perivascular cuffs of lymphocytes, as well as with the MHC-I and MHC-II expression and albumin extravasation/glial uptake within the tumor (Prabowo et al. 2013b). These observations may support the potential relationship between the induction of the immune response and the activation of mTOR, which may represent the link between GNTand other focal epileptogenic developmental lesions, such as FCD and TSC (for reviews, see Crino 2011 and Aronica and Crino 2014).

Whether a deregulation the inflammatory response during brain development may contribute to progressive cognitive dysfunction deserves further investigation (Cohly 2005; Chew et al. 2006; Chavan et al. 2012). Interestingly, evidence of cell injury and premature neurodegeneration has been reported in TSC, FCD, and GNT (Maldonado et al. 2003; Sen et al. 2007; Boer et al. 2008, 2010; Choi et al. 2009; Iyer et al. 2014; Prabowo et al. 2014).

\section{ADAPTIVE IMMUNITY IN EPILEPSY}

The adaptive (or acquired) immune system is the part of the immune system that prepares the body for current and future challenges from pathogens. However, it can also be maladaptive and react to self-antigens, thus resulting in autoimmunity. Both antibody-mediated mechanisms and T-cell cytotoxicity can be involved in epilepsy and other seizure-related disorders. Investigations of the brains of patients with long-standing epilepsies have shown changes indicative of BBB damage with evidence of albumin and IgG extravasation in brain parenchyma (Rigau et al. 2007; van Vliet et al. 2007; Ravizza et al. 2008), although it is unclear how the BBB becomes compromised initially. More recently, a direct role has also been suggested for autoantibodies in seizure-related diseases, such as RE, forms of viral encephalitis, and encephalitides, which are defined by the presence of specific neural antibodies in serum and/or CSF (Table 1). Finally, autoantibodies are now being detected in patients in whom seizures are the predominant presenting symptom (Table 2 ).

\section{Antibody-Associated Encephalitis}

The antibodies associated with the autoimmune encephalitides can be divided into those that are directed against intracellular targets (such as GAD65, amphiphysin, and the oncoantigens $\mathrm{Hu}$, Yo, CRMP5, and Ma2) and antibodies directed to surface receptors and the associated proteins: voltage-gated potassium channel (VGKC)-complex, glutamate (NMDA, AMPA) receptors, and the $\mathrm{GABA}_{\mathrm{A}}$ and $\mathrm{GABA}_{\mathrm{B}}$ receptors. It is unlikely that autoantibodies to intracellular antigens have the potential to be pathogenic and may simply represent a secondary antibody response; however, there is growing evidence that antibodies against surface receptors may have a direct pathogenic role.

\section{Paraneoplastic Encephalitides}

The role of the cellular arm of the adaptive immune system is most obvious in the paraneoplastic encephalitides, in which the serum antibodies detected, so far, are directed against 
A. Vezzani et al.

Table 1. Autoantibodies in seizure-related diseases

\begin{tabular}{|c|c|c|}
\hline Disorder & $\begin{array}{l}\text { Autoantibodies } \\
\text { to }\end{array}$ & $\begin{array}{l}\text { Seizures } \\
\text { (\% patients) }\end{array}$ \\
\hline \multirow[t]{5}{*}{$\begin{array}{l}\text { Limbic } \\
\text { encephalitis }\end{array}$} & $\begin{array}{l}\text { VGKC-complex } \\
\text { (including } \\
\text { LGI1 and } \\
\text { CASPR2) }\end{array}$ & $60-90$ \\
\hline & AMPA-receptor & 40 \\
\hline & $\mathrm{GABA}_{\mathrm{A}}$-receptor & 100 \\
\hline & $\mathrm{GABA}_{\mathrm{B}}$-receptor & 100 \\
\hline & GAD & $\sim 100$ \\
\hline $\begin{array}{l}\text { Encephalitis with } \\
\text { hyperexcitability }\end{array}$ & DPPX & $0-15$ \\
\hline $\begin{array}{l}\text { NMDAR- } \\
\text { encephalitis }\end{array}$ & NMDAR & $77-100$ \\
\hline $\begin{array}{r}\text { Encephalitis } \\
\text { lethargica }\end{array}$ & NMDAR & 50 \\
\hline $\begin{array}{l}\text { Neuromyelitis } \\
\text { optica }\end{array}$ & Aquaporin 4 & 0 \\
\hline \multirow[t]{4}{*}{ Cerebellar ataxia } & VGCC & 0 \\
\hline & GAD & 0 \\
\hline & Amphiphysin & 0 \\
\hline & $\begin{array}{l}\text { mGlutamate- } \\
\text { receptor } 1\end{array}$ & 0 \\
\hline
\end{tabular}

VGKC, Voltage-gated potassium channel; VGCC, voltagegated calcium channel; LGIl, leucine-rich, glioma-inactivated 1; CASPR2, contactin-associated protein-like 2; GABA, $\gamma$-aminobutyric acid; GAD, glutamic acid decarboxylase; NMDA, $N$-methyl-D-aspartate; NMDAR, NMDA receptor.

intracellular antigens. Neuropathological studies have shown $\mathrm{CD}^{+} \mathrm{T}$-cell infiltrates in the central nervous system (CNS), although the direct target antigen of these T cells is unknown (Graus et al. 1990; Posner 1991; Jean et al. 1994; Verschuuren et al. 1996; Giometto et al. 1997; Dalmau et al. 1999; Bien et al. 2012). These T cells, reminiscent of those reported in RE, are found in the vicinity of neurons where they are posed to release cytotoxic granules and may, therefore, be directly involved in neuronal cell death (Tanaka et al. 1998, 1999; Bernal et al. 2002; Bien et al. 2002, 2012; Blumenthal et al. 2006).

\section{RE}

The first epilepsy syndrome in which the autoimmune system was thought to play a significant pathologic role was RE. Rabbits immunized with recombinant glutamate receptor type 3 (GluR3) developed severe seizures and had inflammatory histopathological changes in their brains similar to those found in patients with RE. In addition, antibodies to GluR3 were detected in the sera of some RE patients, and plasma exchange in one child significantly reduced the serum titers of GluR3 antibodies, decreased seizure frequency, and improved neurologic function (Rogers et al. 1994). However, further studies failed to support these findings; anti-GluR3 antibodies were infrequently found in RE or intractable epilepsies (Wiendl et al. 2001; Watson et al. 2004) and few patients showed sustained clinical improvement following plasmapheresis (Andrews et al. 1996; Granata et al. 2003). Additionally, antibodies against a number of other autoantigens, such as the $\alpha 7$ nicotinic receptor or Munc-18-1, have been reported in sera of a few RE patients (Watson et al. 2005; Alvarez-Baron et al. 2008), and the relevance of these antibodies is questionable. However, the presence of autoantibodies suggests that there is activation of the adaptive immune system and may be a secondary phenomenon following the intervention of cytotoxic $\mathrm{T}$ lymphocytes into the brain. Examination of the brains from RE patients have shown that most inflammatory $\mathrm{T}$ cells in the parenchyma are $\mathrm{CD}^{+}$, with $\sim 10 \%$ of these cells being $\mathrm{GrB}^{+}$ cytotoxic $T$ cells. These cells are found polarized toward neurons and astrocytes (Bien et al. 2002; Bauer et al. 2007), and spectratyping of the $T$ cells extracted from active lesions show expansion from discrete epitope-recognizing precursor T cells (Li et al. 1997; Schwab et al. 2009). Although it is unlikely that these $\mathrm{T}$ cells directly cause the seizures, they certainly contribute to the activation of the immune system in these patients and play a major part in the neurodegenerative progression of disease.

\section{NMDA Receptor (NMDAR) Antibodies Encephalitis}

The first of the antibody-mediated encephalitis to be described was NMDAR-antibody encephalitis, associated with autoantibodies against the NR1 subunit of the NMDAR. This disorder was first described in young women presenting 
Immunity and Inflammation in Epilepsy

Table 2. Autoantibodies in epilepsy (cohort studies)

\begin{tabular}{|c|c|c|c|c|c|c|}
\hline Epilepsy & & $N$ & $\begin{array}{c}\text { Positivity } \\
(\%)\end{array}$ & $\begin{array}{c}\text { Autoantibodies } \\
\text { detected }\end{array}$ & Notes & References \\
\hline \multirow[t]{3}{*}{ Mixed } & Total & 139 & $19(13.6)$ & $\begin{array}{c}16 \text { VGKC-c; } \\
3 \text { GAD }\end{array}$ & $\begin{array}{l}\text { Patients with } \\
\text { highest VGKC } \\
\text { titers; all had } \\
\text { short duration } \\
\text { and additional } \\
\text { symptoms } \\
\text { consistent with } \\
\text { LE }\end{array}$ & $\begin{array}{l}\text { McKnight } \\
\text { et al. } \\
2005\end{array}$ \\
\hline & $\begin{array}{l}\text { AID or } \\
\text { suspected/ } \\
\text { AID }\end{array}$ & 72 & $15(21)$ & $\begin{array}{c}14 \text { VGKC-c; } \\
1 \text { GAD }\end{array}$ & VGKC-c high & \\
\hline & DRE & 67 & $4(6)$ & $\begin{array}{l}2 \text { VGKC-c; } \\
2 \text { GAD }\end{array}$ & $\begin{array}{l}\text { VGKC-c low, GAD } \\
\text { titers high }\end{array}$ & \\
\hline Long-standing & Total & 106 (female) & $6(5)$ & $\begin{array}{r}5 \text { VGKC-c; } \\
1 \text { VGCC }\end{array}$ & & $\begin{array}{r}\text { Majoie } \\
\text { et al. } \\
2006\end{array}$ \\
\hline \multirow[t]{3}{*}{ Mixed } & Total & 416 & $46(11)$ & & Highest prevalence & Brenner \\
\hline & $\begin{array}{l}\text { Consecutive } \\
\text { clinic } \\
\text { cohort }\end{array}$ & 235 & $26(11)$ & $\begin{array}{l}8 \text { VGKC-c; } \\
10 \text { GlyR; } \\
3 \text { NMDA; } 4 \\
\text { GAD; } 1 \\
\text { VGKC/GlyR }\end{array}$ & $\begin{array}{l}\text { of antibodies } \\
\text { found in focal } \\
\text { epilepsies of } \\
\text { unknown cause }\end{array}$ & $\begin{array}{l}\text { et al. } \\
2013\end{array}$ \\
\hline & NDC & 181 & $20(11)$ & $\begin{array}{l}12 \text { VGKC-c; } \\
1 \text { GlyR; } 4 \\
\text { NMDA; } 3 \\
\text { GAD }\end{array}$ & & \\
\hline Adult onset & Total & 144 & $6(4.2)$ & $\begin{array}{l}6 \text { VGKC-c (1 } \\
\text { CASPR2; } 1 \\
\text { LGI1) }\end{array}$ & $\begin{array}{l}\text { Only looked for } \\
\text { antibodies to } \\
\text { VGKC-c } \\
\text { (<400 pM); } \\
\text { patients had } \\
\text { favorable } \\
\text { response to } \\
\text { immunotherapy }\end{array}$ & $\begin{array}{l}\text { Lilleker } \\
\text { et al. } \\
2013\end{array}$ \\
\hline Highly selective & $\begin{array}{l}\text { Patients in } \\
\text { whom AID } \\
\text { was known } \\
\text { or highly } \\
\text { suspected }\end{array}$ & 32 & $29(91 \%)$ & $\begin{array}{l}18 \text { VGKC-c } \\
\text { (including } \\
\text { LGI1, } \\
\text { CASPR2); } \\
7 \text { GAD; } \\
2 \text { CRMP5; } \\
1 \text { MA2; } \\
1 \text { NMDAR }\end{array}$ & $\begin{array}{l}\text { Patients were } \\
\text { highly selected } \\
\text { for autoimmune } \\
\text { profile; } \\
\text { immunotherapy } \\
\text { produced } \\
\text { improvement in } \\
81 \% \text { of patients; } \\
18 \text { were seizure } \\
\text { free }\end{array}$ & $\begin{array}{l}\text { Quek et al. } \\
2012\end{array}$ \\
\hline \multirow{2}{*}{$\begin{array}{l}\text { Adult } \\
\text { consecutive } \\
\text { with either }\end{array}$} & Total & 81 & $13(16 \%)$ & & Psychotic attacks, & Ekizogluet \\
\hline & FEoUC & 55 & $7(12.7)$ & $\begin{array}{l}4 \text { GlyR; } \\
2 \text { NMDAR; } \\
1 \text { VGKC-c }\end{array}$ & $\begin{array}{l}\text { nonspecific } \\
\text { MRI, and poor } \\
\text { AED drug }\end{array}$ & $\begin{array}{l}\text { et al. } \\
2014\end{array}$ \\
\hline
\end{tabular}

Continued 
A. Vezzani et al.

Table 2. Continued

\begin{tabular}{|c|c|c|c|c|c|c|}
\hline Epilepsy & & $N$ & $\begin{array}{c}\text { Positivity } \\
(\%)\end{array}$ & $\begin{array}{c}\text { Autoantibodies } \\
\text { detected }\end{array}$ & Notes & References \\
\hline $\begin{array}{l}\text { FEoUC or } \\
\text { MTLE-HS }\end{array}$ & \multirow[t]{2}{*}{ MTLE-HS } & 26 & $6(23.1)$ & $\begin{array}{c}4 \text { CASPR2; } \\
1 \text { GlyR; } 1 \\
\text { VGKC-c }\end{array}$ & $\begin{array}{l}\text { response were } \\
\text { observed in } \\
\text { seropositive } \\
\text { patients }\end{array}$ & \\
\hline Children & & 114 & $11(9.7)$ & $\begin{array}{l}4 \text { VGKC-c; } \\
\text { 3 CASPR2; } \\
2 \text { NMDAR; } 2 \\
\text { NMDAR/ } \\
\text { VGKC-c }\end{array}$ & $\begin{array}{l}\text { Classification of } \\
\text { "unknown cause" } \\
\text { was higher in the } \\
\text { antibody-positive } \\
\text { patients }(63 \%) \\
\text { compared with } \\
\text { the antibody- } \\
\text { negative subjects } \\
(26.7 \%)\end{array}$ & $\begin{array}{l}\text { Suleiman } \\
\text { et al. } \\
2013\end{array}$ \\
\hline
\end{tabular}

AID, Autoimmune disease; VGKC, voltage-gated potassium channel; GAD, glutamic acid decarboxylase; NMDA, $N$ methyl-D-aspartate; NMDAR, NMDA receptor; DRE, drug-resistant epilepsy; LE, limbic encephalitis; CASPR2, contactinassociated protein-like 2; LGI1, leucine-rich, glioma-inactivated 1; VGCC, voltage-gated calcium channel; FEoUC: focal epilepsy of unknown cause; MTLE-HS, mesial temporal lobe epilepsy-hippocampal sclerosis; AED, antiepileptic drugs; MRI, magnetic resonance imaging.

with an ovarian teratoma and, so, initially it was considered to be paraneoplastic (Dalmau et al. 2007, 2008). However, further studies show that this occurs in both men and women, and many patients are nonparaneoplastic (Irani et al. 2010b). Clinically, a prodromal stage with symptoms, such as fever, nausea, vomiting, or diarrhea, can occur (Iizuka et al. 2008). Patients may then go onto developing seizures (partial), status epilepticus, short-term memory loss, and, in addition, often show major psychiatric symptoms, such as anxiety, fear, mania, and paranoia. Without effective treatment, patients will show severe movement disorders and a decrease in consciousness with effects on the autonomic, system, which could result in death (Dalmau et al. 2011). Children as young as 18 months have also been shown to be affected, and it is harder to diagnose (Dale et al. 2009; Florance-Ryan and Dalmau 2010); the outcome is usually good, but the recovery is slow with frequent protracted symptoms.

Despite severe clinical signs, many patients recover completely, but often requiring prolonged courses of immunomodulatory therapy. Obviously, in paraneoplastic patients, most frequently ovarian teratoma, tumor resection plays an important role in clinical improvement. An algorithm for immunotherapy administration to these patients (Dalmau et al. 2011) involves the use of second-line treatments, such as rituximab and cyclophosphamide, when firstline therapies are noneffective. Further studies focusing particularly on the cognitive deficits have shown that there is a long-term morbidity in this disorder, with a good outcome for the patient dependent on early and aggressive treatment (Finke et al. 2012). The brains of these patients show few inflammatory cells (mostly T cells) (Tuzun et al. 2009; Camdessanche et al. 2011; Martinez-Hernandez et al. 2011; Bien et al. 2012) and magnetic resonance imaging (MRI), and pathological studies show that the neuronal loss in most cases is remarkably mild (Dalmau et al. 2007; Iizuka et al. 2010; Bien et al. 2012). The antibodies have been shown to be pathogenic, at least in vitro. Incubation of rodent hippocampal neurons with patient serum IgG has shown marked cross-linking and internalization of the NMDARs, which, theoretically, could lead to a reduction of NMDAR and to a state of reversible NMDAR hypofunction (Hughes et al. 2010). Very recently, a report of a cohort of children who had neurological relapses following an initial Herpes simplex virus encephalitis (HSVE) were shown to have 
antibodies to NMDAR, indicating that neurological relapses after HSVE could be immune mediated.

\section{VGKC Complex Antibodies Encephalitis}

VGKC-complex antibody encephalitis can be found both in paraneoplastic (Buckley et al. 2001) and nonparaneoplastic forms (Thieben et al. 2004; Vincent et al. 2004). Although initially detected by their ability to immunoprecipitate radiolabeled-VGKC-complexes, it has now been shown that these antibodies are mainly directed to accessory proteins rather than the VGKC itself. Three associated proteins have, so far, been recognized: contactin-associated protein-like 2 (CASPR2) (Vincent et al. 2009; Irani et al. 2010a; Vincent and Irani 2010; Lancaster et al. 2011), leucine-rich, glioma-inactivated 1 (LGI1) (Irani et al. 2010a; Lai et al. 2010) and contactin-2 (Irani et al. 2010a). Clinically, these patients present with memory loss, confusion, behavioral changes, and often prominent seizures (Vincent et al. 2004; Chan et al. 2007). Most of these patients do not have an underlying tumor. A useful serum marker appears to be the presence of a hyponatremia. An MRI typically shows a high signal in the temporal lobes, but an increasing number of patients are being diagnosed with normal imaging. However, pathological investigation of brain tissue from patients with VGKC-complex antibodies have shown neuronal degeneration in the hippocampus with infiltrating $\mathrm{T}$ cells (Bien et al. 2012), and the presence of human IgG and components of the complement cascade (Bien et al. 2012). Steroids, intravenous immunoglobulins and plasmapheresis, and, occasionally, cyclophosphamide have been found to improve the neurological deficits, suggesting that the autoantibodies are pathogenic (Vincent et al. 2004; Wong et al. 2010).

\section{Autoantibodies to Glutamic Acid Decarboxylase (GAD)}

Antibodies to the intracellular enzyme GAD are found at low to moderate levels in patients with diabetes. However, high levels of GAD antibodies have been recorded in a number of neurological syndromes, including stiff-person syndrome, cerebellar ataxia, and epilepsy. High GAD levels have been found in $~ 2 \%$ of patients with focal drug-resistant epilepsies (Errichiello et al. 2009; Liimatainen et al. 2009), and 6\% of children with myoclonic epilepsy (Aykutlu et al. 2005). Malter and colleagues (2010) investigated a large cohort $(n=138)$ of recent-onset epilepsy patients of whom nearly half fulfilled the criteria for LE. Antibodies to VGKC-complex antibodies were detected in 10 patients and GAD antibodies in nine patients. The GAD-antibody positive patients were more resistant to immunotherapy and antiepileptic drug (AED) treatments than patients with antibodies to VGKC-complex and, so, represent a nonparaneoplastic chronic form of the disorder, which should be included in the differential diagnosis of TLE (Malter et al. 2010). Immunotherapies offered to these patients have sometimes resulted in benefit, but, overall, the treatment prognosis is poor (Giometto et al. 1999).

Although GAD is an intracellular enzyme and, so, autoantibodies are unlikely to be pathogenic, recent studies have shown that the serum anti-GAD antibody levels inversely correlate with cortical GABA levels as measured by magnetic resonance spectroscopy (Stagg et al. 2010). Direct pathogenic activity of this sera has also been shown electrophysiologically on cultured hippocampal neurons using patchclamp techniques in which application of GAD-positive sera onto cultured hippocampal neurons increases the frequency of the postsynaptic inhibitory potentials (IPSPs) resulting in neuronal inhibition. Although this evidence does not necessarily show a pathogenic role for the anti-GAD antibodies, it supports the hypothesis of pathologically active components being present in the patient's sera (Vianello et al. 2008).

\section{Autoantibodies in Faciobrachial Dystonic Seizures (FBDSs)}

FBDSs have recently been reported as an immunotherapy-responsive disorder associated with 
A. Vezzani et al.

antibodies to the VGKC-complex accessory protein LGI1 (Irani et al. 2008, 2011; Barajas et al. 2009). Patients present with frequent (median of 50 a day), short, unilateral paroxysmal dystonic attacks, in association with sensory auras, automatisms, and cognitive disturbances. EEG changes have been recorded in a number of these patients. FBDSs appear to predate the onset of amnesia, which is seen in the "fullblown" encephalitis (Irani et al. 2011), and it is hypothesized that if an FBDS was identified and treated early enough, then the progression to LE could be avoided. Interestingly, treatment with immunotherapy (corticosteroids) in these patients is particularly effective and, in contrast, FBDSs tend to respond poorly to AEDs (Irani et al. 2011). In a recent study of 10 patients, all of whom received AED initially, in only one patient was the seizure frequency reduced by AEDs; however, on addition of immunotherapy, a reduction of seizure frequency was observed in the other nine patients. As well as being ineffective in these patients, in several cases, side effects that included marked cutaneous reactions were recorded. It is, therefore, reasonable to postulate that FBDSs represent an immunotherapy-responsive form of epilepsy associated with a specific autoantibody to the protein LGI1.

\section{Autoantibodies in Idiopathic Epilepsies}

Although unlikely to be the cause in the majority of cases of epilepsy of unknown source, an increasing number of studies have detected autoantibodies in the sera of a significant minority of patients. Serum autoantibodies to components of the VGKC-complex have been detected in $\sim 7 \%$ of large cohorts of unselected patients with epilepsy (McKnight et al. 2005; Majoie et al. 2006). As more autoantibodies are being discovered, the number of patients in which these autoantibodies are detected is rising. This is especially true in patients with acute or subacute onset focal epilepsy of unknown cause (Table 2), in which TLE with HS can manifest in adult life. Around half of the patients have evidence consistent with an autoimmune process (Bien et al. 2007).

\section{PATHOLOGICAL RELEVANCE OF AUTOANTIBODIES IN EPILEPSY}

Autoantibodies to a large range of neuronal channels, receptors, and accessory proteins have been described in patients with seizure-related disorders. A pathogenic role for these antibodies is suggested by the clinical improvement of the patients to immunomodulatory therapy and the inverse relationship between antibody titer and clinical status. However, the precise mechanism of antibody action is largely unknown. A number of experimental studies have shown modulation, cross-linking, and down-regulation of the target antigen by antibodies to NMDA and AMPA (Lai et al. 2009; Hughes et al. 2010). This down-regulation appeared to dramatically reduce the synaptic localization of NMDARs on the hippocampal neuron; however, in the model system, the effect was reversible and does not explain the role of $\mathrm{T}$ cells in the system. Direct effects of antibodies to AMPA receptors on the electrical currents (mEPSC) on hippocampal neurons were also shown using whole-cell patch-clamp studies, whereas application to cultured hippocampal neurons resulted in a significant reduction in the number and density of the AMPA receptors on the cell surface (Lai et al. 2009).

Similar direct effects were shown by Lalic et al. (2010), who used whole-cell patch-clamp recordings of rat CA3 pyramidal cells in hippocampal slices to investigate the action of VGKCcomplex antibodies. Synaptic stimulation of CA3 neurons incubated in anti-VGKC-c IgG induced epileptiform activity and increased the tonic firing rate.

\section{CONCLUSIONS}

Clinical and experimental studies show the presence of activated inflammatory cells (microglia, astrocytes, and leukocytes) and an increase of various proinflammatory molecules with the induction of the related signaling pathways in brain specimens of various drug-resistant forms of epilepsies. There is also evidence of serum autoantibodies in some forms of epilepsy or seizure disorders. The relative contri- 
bution of the innate and adaptive immune systems to brain inflammation appears to vary depending on the underlying epilepsy etiology. Although activation of innate immunity, chiefly involving glial cells, is commonly observed in brain tissue surgically resected for therapeutic reasons from drug-resistant epilepsies, activated $\mathrm{T}$ cells, or circulating autoantibodies, are restricted to more specific cases.

This evidence highlights a possible pathogenetic role of either innate or adaptive immunity response, or both, in epilepsy. Accordingly, in some cases of drug-refractory seizures, anti-inflammatory or immunosuppressive treatments have therapeutic effects.

The triggering factors of brain inflammation reportedly shown in chronic epilepsy are still hypothetical. In this context, experiments in animal models show that epileptogenic brain injuries (e.g., trauma, hypoxia/ischemia), mimicking bacterial or viral infections (Galic et al. 2008, 2009; Riazi et al. 2010; Stewart et al. 2010), or recurrent seizure activity per se (Vezzani et al. 2011c) can induce a prominent innate immunity response in glia, which activates rapid and self-perpetuating inflammatory processes in brain tissue (Aronica et al. 2012b; Vezzani et al. 2013a,b). Notably, this innate immunity response has a significant role in experimental seizure generation, cell loss, and comorbidities developing in the animals. As yet, no evidence is available that the adaptive immune system can contribute to seizures directly; however, indirect mechanisms can be envisaged via secondary activation of inflammatory processes in glia, cytotoxicity leading to neurodegeneration, or perturbation of BBB permeability.

The challenge for the exploitation of this evidence for therapeutic purposes is to discover the key molecular events inducing pathologic inflammatory changes in the brain, and which are the pivotal mechanisms by which inflammatory cells and related molecules may compromise brain function, thus promoting seizure generation and brain pathology. These aspects are under intensive investigation in animal models of TLE, and increasing findings provide proof-of-concept evidence of anticonvulsive or neuroprotective effects of novel anti-inflamma- tory treatments, which given alone or in combination can inhibit pharmacoresistant seizures and delay the progression of the disease. This encouraging finding may have a high translational impact because various anti-inflammatory treatments effective in animal models are already in clinical use or have been clinically tested in peripheral inflammatory diseases in humans or in other CNS diseases with an inflammatory brain component (ClinicalTrials .gov 2010; Vezzani et al. 2010, 2011a).

\section{ACKNOWLEDGMENTS}

The authors gratefully acknowledge their sources of support, namely, Programme (FP7/20072013) under Grant agreement No. 602102 (EPITARGET) to A.V. and E.A. and No. 602391 (EPISTOP) to E.A.; National Epilepsy Fund "Power of the Small," the Hersenstichting Nederland (NEF 012-12) to E.A.; Fondazione Monzino and Ministero della Salute (915-P11/02/2013) to A.V.; and Epilepsy Research United Kingdom to B.L.

\section{REFERENCES}

Akin D, Ravizza T, Maroso M, Carcak N, Eryigit T, Vanzulli I, Aker RG, Vezzani A, Onat FY. 2011. IL-1 $\beta$ is induced in reactive astrocytes in the somatosensory cortex of rats with genetic absence epilepsy at the onset of spike-andwave discharges, and contributes to their occurrence. Neurobiol Dis 44: 259-269.

Alvarez-Baron E, Bien CG, Schramm J, Elger CE, Becker AJ, Schoch S. 2008. Autoantibodies to Munc18, cerebra plasma cells and B-lymphocytes in Rasmussen encephalitis. Epilepsy Res 80: 93-97.

Andrews PI, Dichter MA, Berkovic SF, Newton MR, McNamara JO. 1996. Plasmapheresis in Rasmussen's encephalitis. Neurology 46: 242-246.

Aronica E, Crino PB. 2011. Inflammation in epilepsy: Clinical observations. Epilepsia 52: 26-32.

Aronica E, Crino PB. 2014. Epilepsy related to developmental tumors and malformations of cortical development. Neurotherapeutics 11: 251-268.

Aronica E, Gorter JA. 2007. Gene expression profile in temporal lobe epilepsy. Neuroscientist 13: 100-108.

Aronica E, Gorter JA, Redeker S, Ramkema M, Spliet WG, van Rijen PC, Leenstra S, Troost D. 2005. Distribution, characterization and clinical significance of microglia in glioneuronal tumours from patients with chronic intractable epilepsy. Neuropathol Appl Neurobiol 31: 280-291.

Aronica E, Boer K, van Vliet EA, Redeker S, Baayen JC, Spliet WG, van Rijen PC, Troost D, da Silva FH, Wadman WJ, et al. 
A. Vezzani et al.

2007. Complement activation in experimental and human temporal lobe epilepsy. Neurobiol Dis 26: 497-511.

Aronica E, Boer K, Becker A, Redeker S, Spliet WG, van Rijen PC, Wittink F, Breit T, Wadman WJ, Lopes da Silva FH, et al. 2008. Gene expression profile analysis of epilepsyassociated gangliogliomas. Neuroscience 151: 272-292.

Aronica E, Fluiter K, Iyer A, Zurolo E, Vreijling J, van Vliet EA, Baayen JC, Gorter JA. 2010. Expression pattern of miR-146a, an inflammation-associated microRNA, in experimental and human temporal lobe epilepsy. Eur $J$ Neurosci 31: 1100-1107.

Aronica E, Becker AJ, Spreafico R. 2012a. Malformations of cortical development. Brain Pathol 22: 380-401.

Aronica E, Ravizza T, Zurolo E, Vezzani A. 2012b. Astrocyte immune response in epilepsy. Glia 60: 1258-1268.

Aykutlu E, Baykan B, Gurses C, Gokyigit A, Saruhan-Direskeneli G. 2005. No association of anti-GM1 and antiGAD antibodies with juvenile myoclonic epilepsy: A pilot study. Seizure 14: 362-366.

Balosso S, Ravizza T, Pierucci M, Calcagno E, Invernizzi RW, Di Giovanni G, Esposito E, Vezzani A. 2009. Molecular and functional interactions between TNF- $\alpha$ receptors and the glutamatergic system in the mouse hippocampus: Implications for seizure susceptibility. Neuroscience 161: $293-300$.

Balosso S, Ravizza T, Aronica E, Vezzani A. 2013. The dual role of TNF- $\alpha$ and its receptors in seizures. Exp Neurol 247C: $267-271$.

Barajas RF, Collins DE, Cha S, Geschwind MD. 2009. Adultonset drug-refractory seizure disorder associated with anti-voltage-gated potassium-channel antibody. Epilepsia 51: 473-477.

Barkovich AJ, Guerrini R, Kuzniecky RI, Jackson GD, Dobyns WB. 2012. A developmental and genetic classification for malformations of cortical development: Update 2012. Brain 135: 1348-1369.

Bauer J, Elger CE, Hans VH, Schramm J, Urbach H, Lassmann H, Bien CG. 2007. Astrocytes are a specific immunological target in Rasmussen's encephalitis. Ann Neurol 62: $67-80$.

Beach TG, Woodhurst WB, MacDonald DB, Jones MW. 1995. Reactive microglia in hippocampal sclerosis associated with human temporal lobe epilepsy. Neurosci Lett 191: $27-30$.

Bellavista E, Andreoli F, Parenti MD, Martucci M, Santoro A, Salvioli S, Capri M, Baruzzi A, Del Rio A, Franceschi C, et al. 2013. Immunoproteasome in cancer and neuropathologies: A new therapeutic target? Curr Pharm Des 19: $702-718$.

Bernal F, Graus F, Pifarre A, Saiz A, Benyahia B, Ribalta T. 2002. Immunohistochemical analysis of anti-Hu-associated paraneoplastic encephalomyelitis. Acta Neuropathol 103: 509-515.

Bianchi ME. 2007. DAMPs, PAMPs and alarmins: All we need to know about danger. J Leukoc Biol 81: 1-5.

Bien CG, Bauer J, Deckwerth TL, Wiendl H, Deckert M, Wiestler OD, Schramm J, Elger CE, Lassmann H. 2002. Destruction of neurons by cytotoxic T cells: A new pathogenic mechanism in Rasmussen's encephalitis. Ann Neurol 51: 311-318.
Bien CG, Urbach H, Schramm J, Soeder BM, Becker AJ, Voltz R, Vincent A, Elger CE. 2007. Limbic encephalitis as a precipitating event in adult-onset temporal lobe epilepsy. Neurology 69: 1236-1244.

Bien CG, Vincent A, Barnett MH, Becker AJ, Blumcke I, Graus F, Jellinger KA, Reuss DE, Ribalta T, Schlegel J, et al. 2012. Immunopathology of autoantibody-associated encephalitides: Clues for pathogenesis. Brain 135: $1622-1638$.

Blumcke I, Vinters HV, Armstrong D, Aronica E, Thom M, Spreafico R. 2009. Malformations of cortical development and epilepsies: Neuropathological findings with emphasis on focal cortical dysplasia. Epileptic Disord 1: $181-193$.

Blumcke I, Thom M, Aronica E, Armstrong DD, Bartolomei F, Bernasconi A, Bernasconi N, Bien CG, Cendes F, Coras $\mathrm{R}$, et al. 2013. International consensus classification of hippocampal sclerosis in temporal lobe epilepsy: A Task Force report from the ILAE Commission on Diagnostic Methods. Epilepsia 54: 1315-1329.

Blumenthal DT, Salzman KL, Digre KB, Jensen RL, Dunson WA, Dalmau J. 2006. Early pathologic findings and longterm improvement in anti-Ma2-associated encephalitis. Neurology 67: 146-149.

Boer K, Spliet WG, van Rijen PC, Redeker S, Troost D, Aronica E. 2006. Evidence of activated microglia in focal cortical dysplasia. J Neuroimmunol 173: 188-195.

Boer K, Jansen F, Nellist M, Redeker S, van den Ouweland AM, Spliet WG, van Nieuwenhuizen O, Troost D, Crino PB, Aronica E. 2008. Inflammatory processes in cortical tubers and subependymal giant cell tumors of tuberous sclerosis complex. Epilepsy Res 78: 7-21.

Boer K, Crino PB, Gorter JA, Nellist M, Jansen FE, Spliet WGM, van Rijen PC, Wittink FRA, Breit TM, Troost D, et al. 2010. Gene expression analysis of tuberous sclerosis complex cortical tubers reveals increased expression of adhesion and inflammatory factors. Brain Pathol 20: 704-719.

Braganza O, Bedner P, Hüttmann K, von Staden E, Friedman A, Seifert G, Steinhäuser C. 2012. Albumin is taken up by hippocampal NG2 cells and astrocytes and decreases gap junction coupling. Epilepsia 53: 1898-906.

Brenner T, Sills GJ, Hart Y, Howell S, Waters P, Brodie MJ, Vincent A, Lang B. 2013. Prevalence of neurologic autoantibodies in cohorts of patients with new and established epilepsy. Epilepsia 54: 1028-1035.

Buckley C, Oger J, Clover L, Tuzun E, Carpenter K, Jackson M, Vincent A. 2001. Potassium channel antibodies in two patients with reversible limbic encephalitis. Ann Neurol 50: 73-78.

Camdessanche JP, Streichenberger N, Cavillon G, Rogemond V, Jousserand G, Honnorat J, Convers P, Antoine JC. 2011. Brain immunohistopathological study in a patient with anti-NMDAR encephalitis. Eur J Neurol 18: 929-931.

Chan D, Henley SM, Rossor MN, Warrington EK. 2007. Extensive and temporally ungraded retrograde amnesia in encephalitis associated with antibodies to voltage-gated potassium channels. Arch Neurol 64: 404-410.

Chavan SS, Huerta PT, Robbiati S, Valdes-Ferrer SI, Ochani M, Dancho M, Frankfurt M, Volpe BT, Tracey KJ, Dia- 
mond B. 2012. HMGB1 mediates cognitive impairment in sepsis survivors. Mol Med 18: 930-937.

Chen MK, Guilarte TR. 2008. Translocator protein $18 \mathrm{kDa}$ (TSPO): Molecular sensor of brain injury and repair. Pharmacol Ther 118: 1-17.

Chew LJ, Takanohashi A, Bell M. 2006. Microglia and inflammation: Impact on developmental brain injuries. Ment Retard Dev Disabil Res Rev 12: 105-112.

Choi J, Nordli DR Jr, Alden TD, DiPatri A Jr, Laux L, Kelley K, Rosenow J, Schuele SU, Rajaram V, Koh S. 2009. Cellular injury and neuroinflammation in children with chronic intractable epilepsy. J Neuroinflammation 6: 38.

ClinicalTrials.gov. 2010. Study of VX-765 in subjects with treatment-resistant partial epilepsy. clinicaltrials.gov/ ct2/show/NCT01048255.

Cosenza-Nashat M, Zhao ML, Suh HS, Morgan J, Natividad R, Morgello S, Lee SC. 2009. Expression of the translocator protein of $18 \mathrm{kDa}$ by microglia, macrophages and astrocytes based on immunohistochemical localization in abnormal human brain. Neuropathol Appl Neurobiol 35: 306-328.

Crespel A, Coubes P, Rousset MC, Brana C, Rougier A, Rondouin G, Bockaert J, Baldy-Moulinier M, Lerner-Natoli M. 2002. Inflammatory reactions in human medial temporal lobe epilepsy with hippocampal sclerosis. Brain Res 952: 159-169.

Crino PB. 2011. mTOR: A pathogenic signaling pathway in developmental brain malformations. Trends Mol Med 17: 734-742.

Dale RC, Irani SR, Brilot F, Pillai S, Webster R, Gill D, Lang B, Vincent A. 2009. $N$-methyl-D-aspartate receptor antibodies in pediatric dyskinetic encephalitis lethargica. Ann Neurol 66: 704-709.

Dalmau J, Gultekin SH, Voltz R, Hoard R, DesChamps T, Balmaceda C, Batchelor T, Gerstner E, Eichen J, Frennier J, et al. 1999. Mal, a novel neuron- and testis-specific protein, is recognized by the serum of patients with paraneoplastic neurological disorders. Brain 122: 27-39.

Dalmau J, Tuzun E, Wu HY, Masjuan J, Rossi JE, Voloschin A, Baehring JM, Shimazaki H, Koide R, King D, et al. 2007. Paraneoplastic anti- $N$-methyl-D-aspartate receptor encephalitis associated with ovarian teratoma. Ann $\mathrm{Neu}$ rol 61: 25-36.

Dalmau J, Gleichman AJ, Hughes EG, Rossi JE, Peng X, Lai M, Dessain SK, Rosenfeld MR, Balice-Gordon R, Lynch DR. 2008. Anti-NMDA-receptor encephalitis: Case series and analysis of the effects of antibodies. Lancet Neurol 7: 1091-1098.

Dalmau J, Lancaster E, Martinez-Hernandez E, Rosenfeld MR, Balice-Gordon R. 2011. Clinical experience and laboratory investigations in patients with anti-NMDAR encephalitis. Lancet Neurol 10: 63-74.

de Lanerolle NC, Lee TS. 2005. New facets of the neuropathology and molecular profile of human temporal lobe epilepsy. Epilepsy Behav 7: 190-203.

Del Rosso M, Fibbi G, Pucci M, Margheri F, Serrati S. 2008. The plasminogen activation system in inflammation. Front Biosci 13: 4667-4686.

De Simoni MG, Perego C, Ravizza T, Moneta D, Conti M, Marchesi F, De Luigi A, Garattini S, Vezzani A. 2000 Inflammatory cytokines and related genes are induced in the rat hippocampus by limbic status epilepticus. Eur J Neurosci 12: 2623-2633.

Devinsky O, Vezzani A, Najjar S, De Lanerolle NC, Rogawski MA. 2013. Glia and epilepsy: Excitability and inflammation. Trends Neurosci 36: 174-184.

Ekizoglu E, Tuzun E, Woodhall M, Lang B, Jacobson L, Icoz S, Bebek N, Gurses C, Gokyigit A, Waters P, et al. 2014. Investigation of neuronal autoantibodies in two different focal epilepsy syndromes. Epilepsia 55: 414-422.

Errichiello L, Perruolo G, Pascarella A, Formisano P, Minetti C, Striano S, Zara F, Striano P. 2009. Autoantibodies to glutamic acid decarboxylase (GAD) in focal and generalized epilepsy: A study on 233 patients. J Neuroimmunol 211: $120-123$.

Fabene PF, Mora GN, Martinello M, Rossi B, Merigo F, Ottoboni L, Bach S, Angiari S, Benati D, Chakir A, et al. 2008. A role for leukocyte-endothelial adhesion mechanisms in epilepsy. Nat Med 14: 1377-1383.

Fabene PF, Bramanti P, Constantin G. 2010. The emerging role for chemokines in epilepsy. J Neuroimmunol 224: $22-27$.

Ferrington DA, Gregerson DS. 2012. Immunoproteasomes: Structure, function, and antigen presentation. Prog $\mathrm{Mol}$ Biol Transl Sci 109: 75-112.

Filibian M, Frasca A, Maggioni D, Micotti E, Vezzani A, Ravizza T. 2012. In vivo imaging of glia activation using $1 \mathrm{H}$-magnetic resonance spectroscopy to detect putative biomarkers of tissue epileptogenicity. Epilepsia 53: 19071916.

Finke C, Kopp UA, Pruss H, Dalmau J, Wandinger KP, Ploner CJ. 2012. Cognitive deficits following antiNMDA receptor encephalitis. J Neurol Neurosurg Psychiatry 83: 195-198.

Florance-Ryan N, Dalmau J. 2010. Update on anti- $N$-methyl-D-aspartate receptor encephalitis in children and adolescents. Curr Opin Pediatr 22: 739-744.

Friedman A, Kaufer D, Heinemann U. 2009. Blood-brain barrier breakdown-inducing astrocytic transformation Novel targets for the prevention of epilepsy. Epilepsy Res 85: $142-149$.

Frigerio F, Frasca A, Weissberg I, Parrella S, Friedman A, Vezzani A, Noé FM. 2012. Long-lasting pro-ictogenic effects induced in vivo by rat brain exposure to serum albumin in the absence of concomitant pathology. Epilepsia 53: 1887-1897.

Galic MA, Riazi K, Heida JG, Mouihate A, Fournier NM, Spencer SJ, Kalynchuk LE, Teskey GC, Pittman QJ. 2008. Postnatal inflammation increases seizure susceptibility in adult rats. J Neurosci 28: 6904-6913.

Galic MA, Riazi K, Henderson AK, Tsutsui S, Pittman QJ. 2009. Viral-like brain inflammation during development causes increased seizure susceptibility in adult rats. $\mathrm{Neu}$ robiol Dis 36: $343-351$.

Galic MA, Riazi K, Pittman QJ. 2012. Cytokines and brain excitability. Front Neuroendocrinol 33: 116-125.

Gantier MP. 2010. New perspectives in MicroRNA regulation of innate immunity. J Interferon Cytokine Res 30: 283-289.

Giometto B, Marchiori GC, Nicolao P, Scaravilli T, Lion A, Bardin PG, Tavolato B. 1997. Sub-acute cerebellar degeneration with anti-Yo autoantibodies: Immunohistochem- 
A. Vezzani et al.

ical analysis of the immune reaction in the central nervous system. Neuropathol Appl Neurobiol 23: 468-474.

Giometto B, Taraloto B, Graus F. 1999. Autoimmunity in paraneoplastic neurological syndromes. Brain Pathol 9: 261-273.

Gorter JA, van Vliet EA, Aronica E, Breit T, Rauwerda H, Lopes da Silva FH, Wadman WJ. 2006. Potential new antiepileptogenic targets indicated by microarray analysis in a rat model for temporal lobe epilepsy. J Neurosci 26: $11083-11110$.

Gorter JA, Iyer A, White I, Colzi A, van Vliet EA, Sisodiya S, Aronica E. 2014. Hippocampal subregion-specific microRNA expression during epileptogenesis in experimental temporal lobe epilepsy. Neurobiol Dis 62: 508-520.

Granata T, Fusco L, Gobbi G, Freri E, Ragona F, Broggi G, Mantegazza R, Giordano L, Villani F, Capovilla G, et al. 2003. Experience with immunomodulatory treatments in Rasmussen's encephalitis. Neurology 61: 1807-1810.

Graus F, Ribalta T, Campo E, Monforte R, Urbano A, Rozman C. 1990. Immunohistochemical analysis of the immune reaction in the nervous system in paraneoplastic encephalomyelitis. Neurology 40: 219-222.

Hirvonen J, Kreisl WC, Fujita M, Dustin I, Khan O, Appel S, Zhang Y, Morse C, Pike VW, Innis RB, et al. 2012. Increased in vivo expression of an inflammatory marker in temporal lobe epilepsy. J Nucl Med 53: 234-240.

Hughes EG, Peng X, Gleichman AJ, Lai M, Zhou L, Tsou R, Parsons TD, Lynch DR, Dalmau J, Balice-Gordon RJ. 2010. Cellular and synaptic mechanisms of anti-NMDA receptor encephalitis. J Neurosci 30: 5866-5875.

Iizuka T, Sakai F, Ide T, Monzen T, Yoshii S, Iigaya M, Suzuki K, Lynch DR, Suzuki N, Hata T, et al. 2008. Anti-NMDA receptor encephalitis in Japan: Long-term outcome without tumor removal. Neurology 70: 504-511.

Iizuka T, Yoshii S, Kan S, Hamada J, Dalmau J, Sakai F, Mochizuki H. 2010. Reversible brain atrophy in antiNMDA receptor encephalitis: A long-term observational study. J Neurol 257: 1686-1691.

Iori V, Maroso M, Rizzi M, Iyer AM, Vertemara R, Carli M, Agresti A, Antonelli A, Bianchi ME, Aronica E, et al. 2013. Receptor for Advanced Glycation Endproducts is upregulated in temporal lobe epilepsy and contributes to experimental seizures. Neurobiol Dis 58: 102-114.

Irani SR, Buckley C, Vincent A, Cockerell OC, Rudge P, Johnson MR, Smith S. 2008. Immunotherapy-responsive seizure-like episodes with potassium channel antibodies. Neurology 71: 1647-1648.

Irani SR, Alexander S, Waters P, Kleopa KA, Pettingill P, Zuliani L, Peles E, Buckley C, Lang B, Vincent A. 2010a. Antibodies to Kv1 potassium channel-complex proteins leucine-rich, glioma inactivated 1 protein and contactinassociated protein-2 in limbic encephalitis, Morvan's syndrome and acquired neuromyotonia. Brain 133: $2734-2748$.

Irani SR, Bera K, Waters P, Zuliani L, Maxwell S, Zandi MS, Friese MA, Galea I, Kullmann DM, Beeson D, et al. 2010b. $N$-methyl-D-aspartate antibody encephalitis: Temporal progression of clinical and paraclinical observations in a predominantly non-paraneoplastic disorder of both sexes. Brain 133: 1655-1667.

Irani SR, Michell AW, Lang B, Pettingill P, Waters P, Johnson MR, Schott JM, Armstrong RJ, S Zagami A, Bleasel A, et al. 2011. Faciobrachial dystonic seizures precede Lgil antibody limbic encephalitis. Ann Neurol 69: 892-900.

Iyer A, Zurolo E, Spliet WG, van Rijen PC, Baayen JC, Gorter JA, Aronica E. 2010a. Evaluation of the innate and adaptive immunity in type I and type II focal cortical dysplasias. Epilepsia 51: 1736-1773.

Iyer AM, Zurolo E, Boer K, Baayen JC, Giangaspero F, Arcella A, Di Gennaro GC, Esposito V, Spliet WGM, van Rijen PC, et al. 2010b. Tissue plasminogen activator and urokinase plasminogen activator in human epileptogenic pathologies. Neuroscience 19: 929-945.

Iyer A, Zurolo E, Prabowo A, Fluiter K, Spliet WG, van Rijen PC, Gorter JA, Aronica E. 2012. MicroRNA-146a: A key regulator of astrocyte-mediated inflammatory response. PLOS ONE 7: e44789.

Iyer A, Prabowo A, Anink J, Spliet WG, van Rijen PC, Aronica E. 2014. Cell injury and premature neurodegeneration in focal malformations of cortical development. Brain Pathol 24: 1-17.

Jean WC, Dalmau J, Ho A, Posner JB. 1994. Analysis of the IgG subclass distribution and inflammatory infiltrates in patients with anti-Hu-associated paraneoplastic encephalomyelitis. Neurology 44: 140-147.

Jimenez-Mateos EM, Henshall DC. 2013. Epilepsy and microRNA. Neuroscience 238: 218-229.

Joensuu T, Tegelberg S, Reinmaa E, Segerstrale M, Hakala P, Pehkonen H, Korpi ER, Tyynela J, Taira T, Hovatta I, et al. 2014. Gene expression alterations in the cerebellum and granule neurons of $\mathrm{Cstb}^{-/-}$mouse are associated with early synaptic changes and inflammation. PLOS ONE 9: e89321.

Kan AA, de Jager W, de Wit M, Heijnen C, van Zuiden M, Ferrier C, van Rijen P, Gosselaar P, Hessel E, van Nieuwenhuizen O, et al. 2012a. Protein expression profiling of inflammatory mediators in human temporal lobe epilepsy reveals co-activation of multiple chemokines and cytokines. J Neuroinflammation 9: 207.

Kan AA, van der Hel WS, Kolk SM, Bos IW, Verlinde SA, van Nieuwenhuizen O, de Graan PN. 2012b. Prolonged increase in rat hippocampal chemokine signalling after status epilepticus. J Neuroimmunol 245: 15-22.

Kulkarni SK, Dhir A. 2009. Cyclooxygenase in epilepsy: From perception to application. Drugs Today (Barc) 45: $135-154$.

Kwon YS, Pineda E, Auvin S, Shin D, Mazarati A, Sankar R. 2013. Neuroprotective and antiepileptogenic effects of combination of anti-inflammatory drugs in the immature brain. J Neuroinflammation 10: 30.

Lai M, Hughes EG, Peng X, Zhou L, Gleichman AJ, Shu H, Mata S, Kremens D, Vitaliani R, Geschwind MD, et al. 2009. AMPA receptor antibodies in limbic encephalitis alter synaptic receptor location. Ann Neurol 65: 424-434.

Lai M, Huijbers MG, Lancaster E, Graus F, Bataller L, BaliceGordon R, Cowell JK, Dalmau J. 2010. Investigation of LGI1 as the antigen in limbic encephalitis previously attributed to potassium channels: A case series. Lancet Neurol 9: 776-785.

Lalic T, Pettingill P, Vincent A, Capogna M. 2010. Human limbic encephalitis serum enhances hippocampal mossy fiber-CA3 pyramidal cell synaptic transmission. Epilepsia 52: $121-131$. 
Lancaster E, Huijbers MG, Bar V, Boronat A, Wong A, Martinez-Hernandez E, Wilson C, Jacobs D, Lai M, Walker RW, et al. 2011. Investigations of caspr2, an autoantigen of encephalitis and neuromyotonia. Ann Neurol 69: $303-$ 311.

Li Y, Uccelli A, Laxer KD, Jeong MC, Vinters HV, Tourtellotte WW, Hauser SL, Oksenberg JR. 1997. Local-clonal expansion of infiltrating T lymphocytes in chronic encephalitis of Rasmussen. J Immunol 158: 1428-1437.

Liimatainen S, Peltola M, Sabater L, Fallah M, Kharazmi E, Haapala AM, Dastidar P, Knip M, Saiz A, Peltola J. 2009. Clinical significance of glutamic acid decarboxylase antibodies in patients with epilepsy. Epilepsia 51: 760-767.

Lilleker JB, Jones MS, Mohanraj R. 2013. VGKC complex antibodies in epilepsy: Diagnostic yield and therapeutic implications. Seizure 22: 776-779.

Lo EH, Wang X, Cuzner ML. 2002. Extracellular proteolysis in brain injury and inflammation: Role for plasminogen activators and matrix metalloproteinases. J Neurosci Res 69: $1-9$.

Lucas SM, Rothwell NJ, Gibson RM. 2006. The role of inflammation in CNS injury and disease. Br J Pharmacol 147: S232-S240.

Majoie HJ, de Baets M, Renier W, Lang B, Vincent A. 2006 Antibodies to voltage-gated potassium and calcium channels in epilepsy. Epilepsy Res 71: 135-141.

Maldonado M, Baybis M, Newman D, Kolson DL, Chen W McKhann G II, Gutmann DH, Crino PB. 2003. Expression of ICAM-1, TNF- $\alpha$, NF- $\kappa$ B, and MAP kinase in tubers of the tuberous sclerosis complex. Neurobiol Dis 14: $279-290$.

Malter MP, Helmstaedter C, Urbach H, Vincent A, Bien CG. 2010. Antibodies to glutamic acid decarboxylase define a form of limbic encephalitis. Ann Neurol 67: 470-478.

Marchi N, Teng Q, Ghosh C, Fan Q, Nguyen MT, Desai NK, Bawa H, Rasmussen P, Masaryk TK, Janigro D. 2010. Blood-brain barrier damage, but not parenchymal white blood cells, is a hallmark of seizure activity. Brain Res 1353: 176-186.

Maroso M, Balosso S, Ravizza T, Liu J, Aronica E, Iyer AM, Rossetti C, Molteni M, Casalgrandi M, Manfredi AA, et al. 2010. Toll-like receptor 4 and high-mobility group box-1 are involved in ictogenesis and can be targeted to reduce seizures. Nat Med 16: 413-419.

Martinez-Hernandez E, Horvath J, Shiloh-Malawsky Y, Sangha N, Martinez-Lage M, Dalmau J. 2011. Analysis of complement and plasma cells in the brain of patients with anti-NMDAR encephalitis. Neurology 77: 589-593.

McKnight K, Jiang Y, Hart Y, Cavey A, Wroe S, Blank M, Shoenfeld Y, Vincent A, Palace J, Lang B. 2005. Serum antibodies in epilepsy and seizure-associated disorders. Neurology 65: 1730-1736.

Mishto M, Ligorio C, Bellavista E, Martucci M, Santoro A, Giulioni M, Marucci G, Franceschi C. 2011. Immunoproteasome expression is induced in mesial temporal lobe epilepsy. Biochem Biophys Res Commun 408: 65-70.

Noé FM, Polascheck N, Frigerio F, Bankstahl M, Ravizza T, Marchini S, Beltrame L, Bandero CR, Loscher W, Vezzani A. 2013. Pharmacological blockade of IL-1 $\beta /$ IL-1 receptor type 1 axis during epileptogenesis provides neuroprotection in two rat models of temporal lobe epilepsy. Neurobiol Dis 59: 183-193.
Omran A, Peng J, Zhang C, Xiang QL, Xue J, Gan N, Kong $\mathrm{H}$, Yin F. 2012. Interleukin-1 $\beta$ and microRNA-146a in an immature rat model and children with mesial temporal lobe epilepsy. Epilepsia 53: 1215-1224.

Oprica M, Eriksson C, Schultzberg M. 2003. Inflammatory mechanisms associated with brain damage induced by kainic acid with special reference to the interleukin-1 system. J Cell Mol Med 7: 127-140.

PernhorstK, Herms S, Hoffmann P, Cichon S, Schulz H, Sander T, Schoch S, Becker AJ, Grote A. 2013. TLR4, ATF-3 and IL8 inflammation mediator expression correlates with seizure frequency in human epileptic brain tissue. Seizure 22: 675-678.

Pineda E, Shin D, You SJ, Auvin S, Sankar R, Mazarati A. 2013. Maternal immune activation promotes hippocampal kindling epileptogenesis in mice. Ann Neurol 74: 11-19.

Pitkanen A, Engel J Jr. 2014. Past and present definitions of epileptogenesis and its biomarkers. Neurotherapeutics 11: $231-241$.

Pitkanen A, Lukasiuk K. 2011. Mechanisms of epileptogenesis and potential treatment targets. Lancet Neurol 10: $173-186$.

Posner JB. 1991. Paraneoplastic syndromes. Neurol Clin 9: 919-936.

Prabowo AS, Anink JJ, Lammens M, Nellist M, van den Ouweland AM, Adle-Biassette H, Sarnat HB, Flores-Sarnat L, Crino PB, Aronica E. 2012. Fetal brain lesions in tuberous sclerosis complex: TORC1 activation and inflammation. Brain Pathol 23: 45-59.

Prabowo AS, Iyer AM, Anink JJ, Spliet WG, van Rijen PC, Aronica E. 2013a. Differential expression of major histocompatibility complex class I in developmental glioneuronal lesions. J Neuroinflammation 10: 12.

Prabowo AS, Iyer AM, Veersema TJ, Anink JJ, Schouten-van Meeteren AY, Spliet WG, van Rijen PC, Ferrier CH, Capper D, Thom M, et al. 2013b. BRAF V600E mutation is associated with mTOR signaling activation in glioneuronal tumors. Brain Pathol 24: 52-66.

Prabowo AS, Iyer AM, Veersema TJ, Anink JJ, Schouten-van Meeteren AY, Spliet WG, van Rijen PC, Ferrier CH, Thom M, Aronica E. 2014. Expression of neurodegenerative disease-related proteins and caspase- 3 in glioneuronal tumours. Neuropathol Appl Neurobiol 41: e1-e15.

Quek AM, Britton JW, McKeon A, So E, Lennon VA, Shin C, Klein C, Watson RE Jr, Kotsenas AL, Lagerlund TD, et al. 2012. Autoimmune epilepsy: Clinical characteristics and response to immunotherapy. Arch Neurol 69: 582-593.

Quinn SR, O'Neill LA. 2011. A trio of microRNAs that control Toll-like receptor signalling. Int Immunol 23: 421425.

Ravizza T, Boer K, Redeker S, Spliet WG, van Rijen PC, Troost D, Vezzani A, Aronica E. 2006. The IL-1 $\beta$ system in epilepsy-associated malformations of cortical development. Neurobiol Dis 24: 128-143.

Ravizza T, Gagliardi B, Noé F, Boer K, Aronica E, Vezzani A. 2008. Innate and adaptive immunity during epileptogenesis and spontaneous seizures: Evidence from experimental models and human temporal lobe epilepsy. Neurobiol Dis 29: $142-160$. 
A. Vezzani et al.

Riazi K, Galic MA, Pittman QJ. 2010. Contributions of peripheral inflammation to seizure susceptibility: Cytokines and brain excitability. Epilepsy Res 89: 34-42.

Rigau V, Morin M, Rousset MC, de Bock F, Lebrun A, Coubes P, Picot MC, Baldy-Moulinier M, Bockaert J, Crespel A, et al. 2007. Angiogenesis is associated with blood-brain barrier permeability in temporal lobe epilepsy. Brain 130: 1942-1956.

Rogers SW, Andrews PI, Gahring LC, Whisenand T, Cauley K, Crain B, Hughes TE, Heinemann SF, McNamara JO. 1994. Autoantibodies to glutamate receptor GluR3 in Rasmussen's encephalitis. Science 265: 648-651.

Rojas A, Jiang J, Ganesh T, Yang MS, Lelutiu N, Gueorguieva P, Dingledine R. 2014. Cyclooxygenase-2 in epilepsy. Epilepsia 55: 17-25.

Roseti C, Fucile S, Lauro C, Martinello K, Bertollini C, Esposito V, Mascia A, Catalano M, Aronica E, Limatola C, et al. 2013. Fractalkine/CX3CL1 modulates $\mathrm{GABA}_{\mathrm{A}}$ currents in human temporal lobe epilepsy. Epilepsia 54: $1834-1844$.

Schmitz AK, Grote A, Raabe A, Urbach H, Friedman A, von Lehe M, Becker AJ, Niehusmann P. 2013. Albumin storage in neoplastic astroglial elements of gangliogliomas. Seizure 22: 144-150.

Schwab N, Bien CG, Waschbisch A, Becker A, Vince GH, Dornmair K, Wiendl H. 2009. CD8 ${ }^{+}$T-cell clones dominate brain infiltrates in Rasmussen encephalitis and persist in the periphery. Brain 132: 1236-1246.

Sen A, Thom M, Martinian L, Harding B, Cross JH, Nikolic M, Sisodiya SM. 2007. Pathological tau tangles localize to focal cortical dysplasia in older patients. Epilepsia 48: 1447-1454.

Sheng JG, Boop FA, Mrak RE, Griffin WS. 1994. Increased neuronal $\beta$-amyloid precursor protein expression in human temporal lobe epilepsy: Association with interleukin-1 $\alpha$ immunoreactivity. J Neurochem 63: 1872-1879.

Sisodiya SM, Fauser S, Cross JH, Thom M. 2009. Focal cortical dysplasia type II: Biological features and clinical perspectives. Lancet Neurol 8: 830-843.

Sonkoly E, Stahle M, Pivarcsi A. 2008. MicroRNAs and immunity: Novel players in the regulation of normal immune function and inflammation. Semin Cancer Biol 18: $131-140$.

Stagg CJ, Lang B, Best JG, McKnight K, Cavey A, JohansenBerg H, Vincent A, Palace J. 2010. Autoantibodies to glutamic acid decarboxylase in patients with epilepsy are associated with low cortical GABA levels. Epilepsia 51: 1898-1901.

Stellwagen D, Beattie EC, Seo JY, Malenka RC. 2005. Differential regulation of AMPA receptor and GABA receptor trafficking by tumor necrosis factor- $\alpha$. J Neurosci 25 : 3219-3228.

Stewart KA, Wilcox KS, Fujinami RS, White HS. 2010. Development of postinfection epilepsy after Theiler's virus infection of C57BL/6 mice. J Neuropathol Exp Neurol 69: $1210-1219$.

Suleiman J, Wright S, Gill D, Brilot F, Waters P, Peacock K, Procopis P, Nibber A, Vincent A, Dale RC, et al. 2013. Autoantibodies to neuronal antigens in children with new-onset seizures classified according to the revised ILAE organization of seizures and epilepsies. Epilepsia 54: $2091-2100$.
Tanaka M, Tanaka K, Shinozawa K, Idezuka J, Tsuji S. 1998. Cytotoxic $\mathrm{T}$ cells react with recombinant Yo protein from a patient with paraneoplastic cerebellar degeneration and anti-Yo antibody. J Neurol Sci 161: 88-90.

Tanaka K, Tanaka M, Inuzuka T, Nakano R, Tsuji S. 1999. Cytotoxic T lymphocyte-mediated cell death in paraneoplastic sensory neuronopathy with anti-Hu antibody. $J$ Neurol Sci 163: 159-162.

Tegelberg S, Kopra O, Joensuu T, Cooper JD, Lehesjoki AE. 2012. Early microglial activation precedes neuronal loss in the brain of the $\mathrm{Cstb}^{-/-}$mouse model of progressive myoclonus epilepsy, EPM1. J Neuropathol Exp Neurol 71: $40-53$.

Thieben MJ, Lennon VA, Boeve BF, Aksamit AJ, Keegan M, Vernino S. 2004. Potentially reversible autoimmune limbic encephalitis with neuronal potassium channel antibody. Neurology 62: 1177-1182.

Thom M, Blumcke I, Aronica E. 2012. Long-term epilepsyassociated tumors. Brain Pathol 22: 350-379.

Tsan MF, Gao B. 2004. Endogenous ligands of Toll-like receptors. J Leukoc Biol 76: 514-519.

Tuzun E, Zhou L, Baehring JM, Bannykh S, Rosenfeld MR, Dalmau J. 2009. Evidence for antibody-mediated pathogenesis in anti-NMDAR encephalitis associated with ovarian teratoma. Acta Neuropathol 118: 737-743.

Ulevitch RJ, Tobias PS. 1995. Receptor-dependent mechanisms of cell stimulation by bacterial endotoxin. Annu Rev Immunol 13: 437-457.

van Gassen KL, de Wit M, Koerkamp MJ, Rensen MG, van Rijen PC, Holstege FC, Lindhout D, de Graan PN. 2008. Possible role of the innate immunity in temporal lobe epilepsy. Epilepsia 49: 1055-1065.

van Vliet EA, da Costa Araujo S, Redeker S, van Schaik R, Aronica E, Gorter JA. 2007. Blood-brain barrier leakage may lead to progression of temporal lobe epilepsy. Brain 130: $521-534$.

van Vliet EA, Zibell G, Pekcec A, Schlichtiger J, Edelbroek PM, Holtman L, Aronica E, Gorter JA, Potschka H. 2010. COX-2 inhibition controls P-glycoprotein expression and promotes brain delivery of phenytoin in chronic epileptic rats. Neuropharmacology 58: 404-412.

Verschuuren J, Chuang L, Rosenblum MK, Lieberman F, Pryor A, Posner JB, Dalmau J. 1996. Inflammatory infiltrates and complete absence of Purkinje cells in anti-Yoassociated paraneoplastic cerebellar degeneration. Acta Neuropathol 91: 519-525.

Vezzani A, Friedman A. 2011. Brain inflammation as a biomarker in epilepsy. Biomark Med 5: 607-614.

Vezzani A, Balosso S, Maroso M, Zardoni D, Noé F, Ravizza T. 2010. ICE/caspase 1 inhibitors and IL-1 $\beta$ receptor antagonists as potential therapeutics in epilepsy. Curr Opin Investig Drugs 11: 43-50.

Vezzani A, Bartfai T, Bianchi M, Rossetti C, French J. 2011a. Therapeutic potential of new antiinflammatory drugs. Epilepsia 52: 67-69.

Vezzani A, French J, Bartfai T, Baram TZ. 2011b. The role of inflammation in epilepsy. Nat Rev Neurol 7: 31-40.

Vezzani A, Maroso M, Balosso S, Sanchez MA, Bartfai T. 2011c. IL-1 receptor/Toll-like receptor signaling in infection, inflammation, stress and neurodegeneration cou- 
ples hyperexcitability and seizures. Brain Behav Immun 25: $1281-1289$.

Vezzani A, Aronica E, Mazarati A, Pittman QJ. 2013a. Epilepsy and brain inflammation. Exp Neurol 244: 11-21.

Vezzani A, Friedman A, Dingledine RJ. 2013b. The role of inflammation in epileptogenesis. Neuropharmacology 69: $16-24$

Vianello M, Bisson G, Dal Maschio M, Vassanelli S, Girard S, Mucignat C, Fountzoulas K, Giometto B. 2008. Increased spontaneous activity of a network of hippocampal neurons in culture caused by suppression of inhibitory potentials mediated by anti-gad antibodies. Autoimmunity 41: 66-73.

Vincent A, Irani SR. 2010. Caspr2 antibodies in patients with thymomas. J Thorac Oncol 5: S277-S280.

Vincent A, Buckley C, Schott JM, Baker I, Dewar BK, Detert N, Clover L, Parkinson A, Bien CG, Omer S, et al. 2004. Potassium channel antibody-associated encephalopathy: A potentially immunotherapy-responsive form of limbic encephalitis. Brain 127: 701-712.

Vincent A, Buckley C, Lang B, Irani S. 2009. Clinical spectrum of voltage-gated potassium channel autoimmunity. Neurology 72: 99; author reply 99-100.

Viviani B, Gardoni F, Marinovich M. 2007. Cytokines and neuronal ion channels in health and disease. Int Rev Neurobiol 82: 247-263.

Watson R, Jiang Y, Bermudez I, Houlihan L, Clover L, McKnight K, Cross JH, Hart IK, Roubertie A, Valmier $\mathrm{J}$, et al. 2004. Absence of antibodies to glutamate receptor type 3 (GluR3) in Rasmussen encephalitis. Neurology 63 : 43-50.

Watson R, Jepson JE, Bermudez I, Alexander S, Hart Y McKnight K, Roubertie A, Fecto F, Valmier J, Sattelle DB, et al. 2005. $\alpha$ 7-acetylcholine receptor antibodies in
Immunity and Inflammation in Epilepsy

two patients with Rasmussen encephalitis. Neurology 65: $1802-1804$.

Weinberg MS, Blake BL, McCown TJ. 2013. Opposing actions of hippocampus TNF $\alpha$ receptors on limbic seizure susceptibility. Exp Neurol 247: 429-437.

Wiendl H, Bien CG, Bernasconi P, Fleckenstein B, Elger CE, Dichgans J, Mantegazza R, Melms A. 2001. GluR3 antibodies: Prevalence in focal epilepsy but no specificity for Rasmussen's encephalitis. Neurology 57: 15111514.

Wong M, Crino PB. 2012. Tuberous sclerosis and epilepsy: Role of astrocytes. Glia 60: 1244-1250.

Wong SH, Saunders MD, Larner AJ, Das K, Hart IK. 2010 An effective immunotherapy regimen for VGKC antibody-positive limbic encephalitis. J Neurol Neurosurg Psychiatry 81: 1167-1169.

Xiong ZQ, Qian W, Suzuki K, McNamara JO. 2003. Formation of complement membrane attack complex in mammalian cerebral cortex evokes seizures and neurodegeneration. J Neurosci 23: 955-960.

Xu Y, Zeng K, Han Y, Wang L, Chen D, Xi Z, Wang H, Wang X, Chen G. 2012. Altered expression of CX3CL1 in patients with epilepsy and in a rat model. Am J Pathol 180: 1950-1962.

Zattoni M, Mura ML, Deprez F, Schwendener RA, Engelhardt B, Frei K, Fritschy JM. 2011. Brain infiltration of leukocytes contributes to the pathophysiology of temporal lobe epilepsy. J Neurosci 31: 4037-4050.

Zurolo E, Iyer A, Maroso M, Carbonell C, Anink JJ, Ravizza T, Fluiter K, Spliet GWM, van Rijen PC, Vezzani A, et al. 2011. Activation of TLR, RAGE and HMGB1 signaling in malformations of cortical development. Brain 134: $1015-1032$. 


\title{
$\&_{\mathrm{CSH}}^{\infty} \&$ Cold Spring Harbor

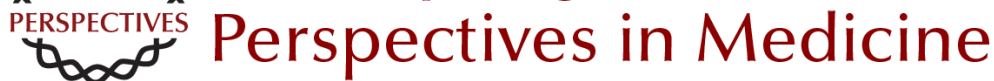

\section{Immunity and Inflammation in Epilepsy}

\author{
Annamaria Vezzani, Bethan Lang and Eleonora Aronica
}

Cold Spring Harb Perspect Med 2016; doi: 10.1101/cshperspect.a022699 originally published online December 18, 2015

\section{Subject Collection Epilepsy: The Biology of a Spectrum Disorder}

The Epilepsy Spectrum: Targeting Future Research Challenges

Gregory L. Holmes and Jeffrey L. Noebels

Role of Sodium Channels in Epilepsy

David I. Kaplan, Lori L. Isom and Steven Petrou

\section{Mechanisms of Action of Antiseizure Drugs and the Ketogenic Diet \\ Michael A. Rogawski, Wolfgang Löscher and Jong M. Rho}

Epilepsy and Autism

Ashura W. Buckley and Gregory L. Holmes

Immunity and Inflammation in Epilepsy Annamaria Vezzani, Bethan Lang and Eleonora Aronica

Hyperpolarization-Activated Cyclic

Nucleotide-Gated (HCN) Channels in Epilepsy Gary P. Brennan, Tallie Z. Baram and Nicholas P. Poolos

The Role of Calcium Channels in Epilepsy Sanjeev Rajakulendran and Michael G. Hanna

Interneuron Transplantation as a Treatment for Epilepsy

Robert F. Hunt and Scott C. Baraban
Common Mechanisms Underlying

Epileptogenesis and the Comorbidities of

Epilepsy

Andrey Mazarati and Raman Sankar

The Diathesis-Epilepsy Model: How Past Events Impact the Development of Epilepsy and

Comorbidities

Christophe Bernard

Potassium Channels in Epilepsy

Rüdiger Köhling and Jakob Wolfart

GABAergic Synchronization in Epilepsy Roustem Khazipov

Status Epilepticus

Syndi Seinfeld, Howard P. Goodkin and Shlomo Shinnar

Neonatal and Infantile Epilepsy: Acquired and

Genetic Models Aristea S. Galanopoulou and Solomon L. Moshé

Epigenetics and Epilepsy

David C. Henshall and Katja Kobow

Microcircuits in Epilepsy: Heterogeneity and Hub Cells in Network Synchronization

Anh Bui, Hannah K. Kim, Mattia Maroso, et al.

For additional articles in this collection, see http://perspectivesinmedicine.cshlp.org/cgi/collection/ 